\title{
Sensitive and affordable diagnostic assay for the quantitative detection of anaplastic lymphoma kinase (ALK) alterations in patients with non-small cell lung cancer
}

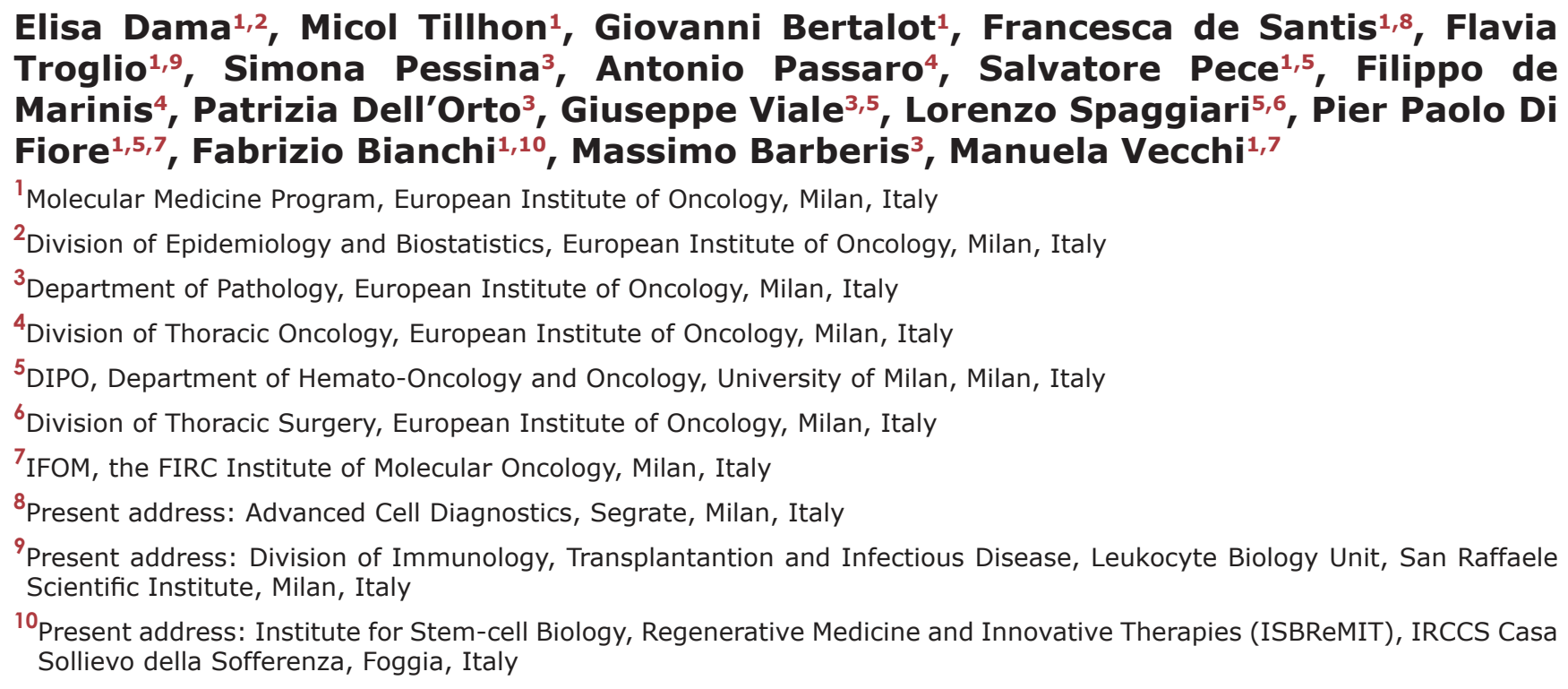

Correspondence to: Manuela Vecchi, email: manuela.vecchi@ieo.eu

Keywords: ALK, RT-qPCR, inverse prediction, FFPE NSCLC, cytology specimens

Received: January 04, 2016

Accepted: April 25, 2016

Published: May 19, 2016

\section{ABSTRACT}

Accurate detection of altered anaplastic lymphoma kinase (ALK) expression is critical for the selection of lung cancer patients eligible for ALK-targeted therapies. To overcome intrinsic limitations and discrepancies of currently available companion diagnostics for ALK, we developed a simple, affordable and objective PCR-based predictive model for the quantitative measurement of any ALK fusion as well as wildtype ALK upregulation. This method, optimized for low-quantity/-quality RNA from FFPE samples, combines CDNA pre-amplification with ad hoc generated calibration curves. All the models we derived yielded concordant predictions when applied to a cohort of 51 lung tumors, and correctly identified all 17 ALK FISH-positive and 33 of the 34 ALK FISH-negative samples. The one discrepant case was confirmed as positive by IHC, thus raising the accuracy of our test to $100 \%$. Importantly, our method was accurate when using low amounts of input RNA (10 $\mathrm{ng})$, also in FFPE samples with limited tumor cellularity (5-10\%) and in FFPE cytology specimens. Thus, our test is an easily implementable diagnostic tool for the rapid, efficacious and cost-effective screening of ALK status in patients with lung cancer.

\section{INTRODUCTION}

The anaplastic lymphoma kinase (ALK) is a transmembrane receptor tyrosine kinase involved in the pathogenesis of different types of human cancers, including anaplastic large-cell lymphoma, neuroblastoma and nonsmall cell lung cancer (NSCLC) [1-4]. In NSCLC, $A L K$ is rearranged in approximately $3-7 \%$ of all patients [4-7], and in $20-30 \%$ of the subset of lung adenocarcinoma patients who are young and non-/light smokers [6-8]. 
$A L K$ (2p23) rearranges primarily with the echinoderm microtubule-associated protein-like 4 (EML4, $2 \mathrm{p} 21)$ in NSCLC leading to the expression of the EML4$A L K$ fusion oncogene [4, 5]. Several EML4-ALK fusion variants have been identified in NSCLC [9], as well as other less-frequent $A L K$ translocations involving different fusion partners [5, 10-14]. While $A L K$ expression is negligible in the normal lung adult tissue [4], these genetic rearrangements lead to the constitutive expression of chimeric proteins comprised of the kinase domaincontaining C-terminus of ALK fused to the N-terminus of the translocation partner, which directs ligand-independent dimerization and activation of ALK $[4,5]$. In addition to $A L K$ rearrangements, $A L K$ gene amplification has also been detected in NSCLC $[7,15,16]$, which might represent an additional mechanism of ALK activation, although its clinical significance is yet to be determined [15].

The identification of $A L K$ translocations in NSCLC has opened the door to the use of targeted therapies for the treatment of these lung cancers. Crizotinib is a welltolerated first generation ALK inhibitor $[17,18]$ that has been shown to be superior to standard chemotherapy both as a first- and second-line treatment $[19,20]$, while second generation ALK inhibitors, such as alectinib and ceritinib, are effective not only in crizotinib-naïve patients, but also in those patients with acquired resistance to crizotinib [21-24]. The availability of these targeted therapies has prompted the development of diagnostic assays and algorithms that can accurately identify ALK-positive lung cancers patients. Although several methodologies have been developed, they display discrepant results [25-31] and often have limited applicability to formalinfixed, paraffin-embedded (FFPE) tissue samples, the major source material for diagnostic testing [25]. Thus, a consensus on the optimal technique and testing algorithm has not yet been reached in the clinical setting $[25,32]$.

Two leading FDA approved ALK diagnostic tests are the break-apart fluorescence in situ hybridization (FISH) assay (Vysis ALK Break Apart FISH Probe Kit), and the automated immunohistochemistry (IHC) assay (Ventana ALK (D5F3) CDx Assay). These two tests show a good level of correlation [33] and in a recent international interpretation study they demonstrated an overall sensitivity, specificity and accuracy of 90\%, 95\% and 93\%, respectively [34]. However, the use of alternative approaches, i.e. reverse transcription-polymerase chain reaction (RT-PCR) and/or next-generation sequencing (NGS), has been recommended to resolve discordant or borderline cases $[35,36]$.

Real-time PCR represents a more quantitative and sensitive technology with reduced inter-observer variability, when compared with FISH and IHC. Yet, some limitations prevent its full implementation in the clinical setting. Firstly, established multiplex RT-PCR assays for the detection of all the different $A L K$ rearrangements require continuous optimization, given the increasing numbers of fusion variants and partners identified [37, 38]. Secondly, more recent reverse transcription quantitative real-time PCR (RT-qPCR) assays based on the unbalanced expression of the $5^{\prime}$ and $3^{\prime}$ portions of the $A L K$ transcript [39-41], which occurs when $A L K$ is rearranged, require significant amounts of RNA (50-100 ng per PCR reaction) from FFPE tissues [40, 41]. Alternative technologies that could be applied to the detection of $A L K$ rearrangements, i.e., NanoString (NanoString Technologies, Inc., Seattle, WA) and RNA massive parallel sequencing require, in addition to elevated amounts of total RNA, the availability of proprietary and cutting-edge platforms in pathology laboratories [42, 43]. To circumvent these problems, we describe herein, a simple quantitative PCR-based ALK predictive model fully optimized to work with low-quantity and low-quality RNA from FFPE samples. The test, by targeting both the $5^{\prime}$ and $3^{\prime}$ portions of $A L K$ mRNA, detects any $A L K$ translocation as well as overexpression of full-length $A L K$.

\section{RESULTS}

\section{Optimization of the RT-qPCR assay for the detection of $A L K$ alterations in FFPE NSCLC samples}

The breakpoint of $A L K$ occurs, by and large, before its intracellular kinase domain (exon 20). When $A L K$ is translocated, its C-terminal portion (exons 20-29) is consistently expressed in the chimeric transcript while its N-terminal part (exons 1-19) is lost. Therefore, measuring the unbalanced expression of the $\mathrm{C}$ - and $\mathrm{N}$-terminal portions of the $A L K$ transcript in a given sample is a reliable method to indirectly identify $A L K$ rearrangements, regardless of fusion partner and variant type. Based on this rationale, we selected two different RTqPCR assays, one targeting exons 27-28 in the 3' region and the other targeting exons $9-10$ in the 5' region of $A L K$ (Figure 1A). In this way, our test is able to detect both known and unknown $A L K$ fusions as well as wild-type $A L K$ upregulation.

To optimize the RT-qPCR analysis of $A L K$ expression from limited amounts of degraded RNA from FFPE tissues, we selected probes targeting short regions ( $<90$ bp in size) of the transcript to increase the probability of detection. We also implemented a multiplex pre-amplification method designed for the dual purpose of stretching precious sample material into more qPCR reactions and of improving the signal-to-noise ratio for the detection of low/moderate-abundance transcripts.

To test the specificity of the two ALK assays, we employed RNA from FFPE samples of: i) Kelly cells expressing readily detectable levels of full-length $A L K$ transcript, containing both the $3^{\prime}$ and $5^{\prime}$ portions of $A L K$ mRNA [2]; ii) NCI-H2228 cells expressing an EML4- 
$A L K$ translocation, thus positive only for the $3^{\prime}$ portion of the $A L K$ mRNA [5]; iii) A549 cells expressing barely detectable levels of the normal $A L K$ transcript, used as a negative control [5].

As expected, the $3^{\prime}$ assay detected $A L K$ expression levels only in Kelly and NCI-H2228 cells, while the 5' ALK assay was positive only in Kelly cells (Figure 1B). When the assays were tested on fresh-frozen (FF) samples of the above cell lines and compared with the results from the FFPE samples, similar expression patterns were detected (Supplementary Table S1). Importantly, the relative expression patterns of both the $3^{\prime}$ and $5^{\prime}$ portions of the $A L K$ transcript were comparable in the three FFPE cell lines with and without pre-amplification, indicating an equal and efficient pre-amplification of cDNA for all the selected targets (Figure 1B and Supplementary Table S1). Indeed, the mean pre-amplification uniformity values $(\Delta \Delta \mathrm{Cq})$ relative to the two ALK assays, measured in Kelly cells were largely within the \pm 1.5 value that is generally accepted for uniform pre-amplification reactions (5' ALK $\Delta \Delta$ Cq: $-0.09 \pm 0.20 ; 3^{\prime}$ ALK $\Delta \Delta$ Cq: $0.01 \pm 0.14$; Supplementary Table S2). In addition, pre-amplification resulted in mean $\mathrm{Cq}$ improvements of around 8 cycles: e.g., $7.85 \pm 0.13$ cycles (range: 7.64-7.99) in Kelly cells (see Supplementary Table S3 for a complete analysis of the 3 cell lines).

\section{A}

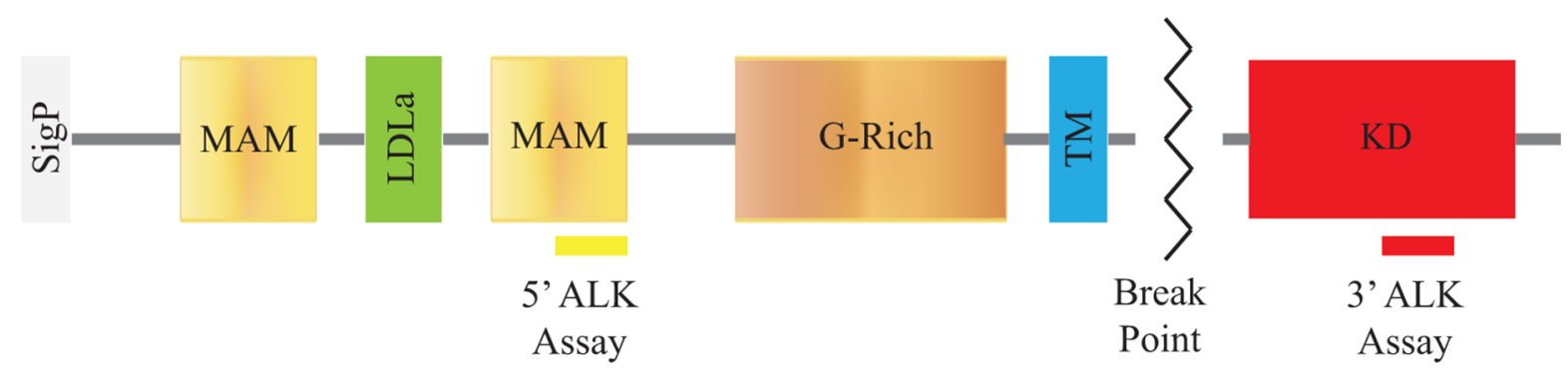

B

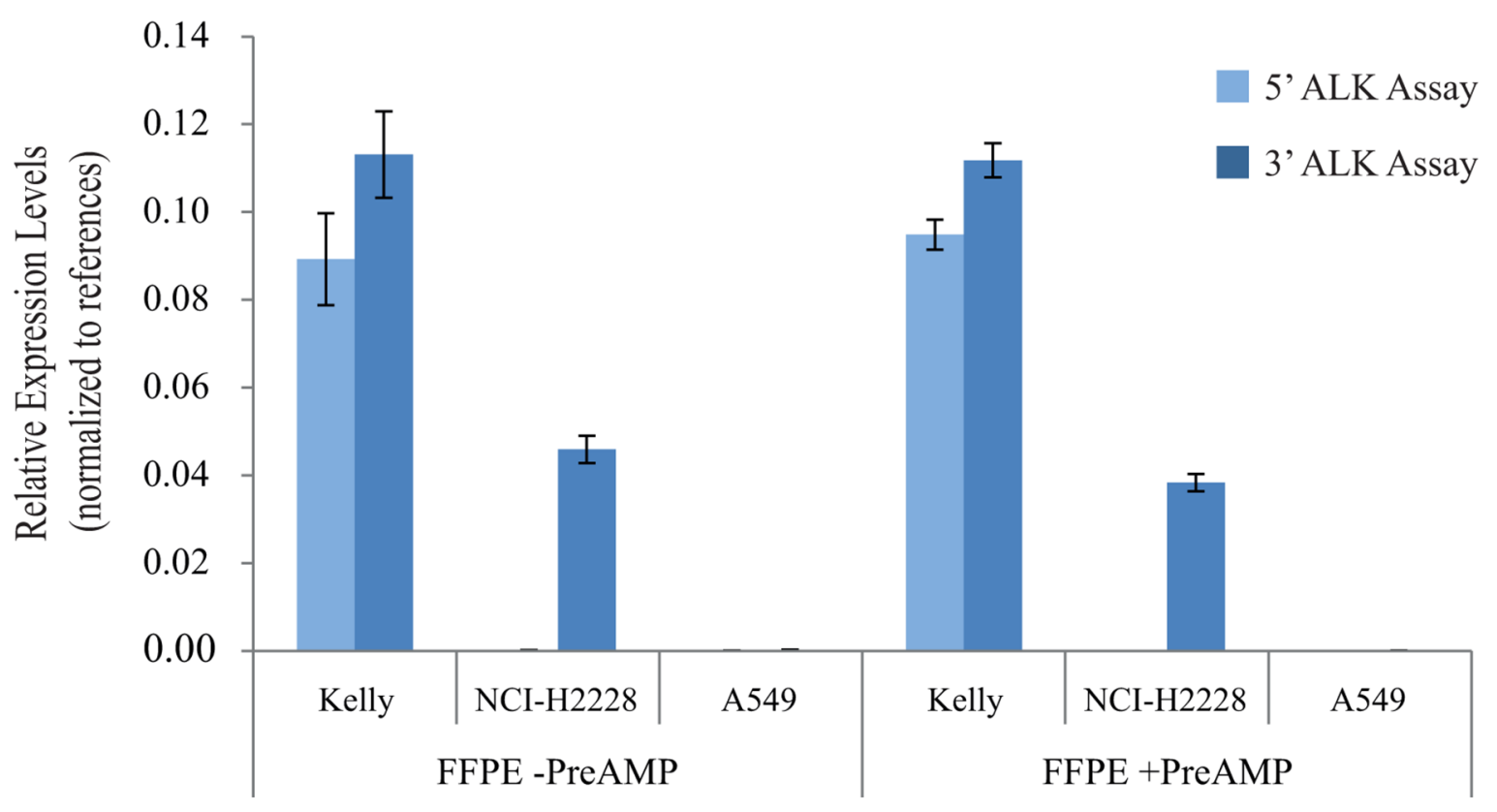

Figure 1: Optimization of the RT-qPCR assays for the detection of the $\boldsymbol{A} \boldsymbol{L} \boldsymbol{K}$ transcript. (A) The position of the two different ALK PCR assays relative to the domain structure of the ALK protein is shown. SigP, signal peptide; MAM (meprin, A-5 protein, and receptor protein-tyrosine phosphatase mu) domains; LDLa (Low-density lipoprotein receptor domain class A) domain; G-rich domain (glycine-rich); TM (Transmembrane) domain; KD (kinase domain). The $A L K$ breakpoint that leads to fusion proteins in different cancers is indicated (zigzag line). (B) Relative expression levels of the $5^{\prime}$ and $3^{\prime}$ portions of the $A L K$ transcript calculated using the formula $2^{-\Delta \mathrm{Cq}}$ (where $\Delta \mathrm{Cq}=\mathrm{Cq}_{\mathrm{ALK}}$ - average $\mathrm{Cq}_{\mathrm{REF}}$ ) in FFPE Kelly, NCI-H2228, and A549 cells with (+ PreAMP) or without (- PreAMP) preamplification are reported. Error bars indicate $95 \%$ confidence intervals (three independent experiments, $n=3$ ). 


\section{Development of an accurate model to predict ALK expression}

To predict accurately the expression levels of the $5^{\prime}$ and $3^{\prime}$ portions of $A L K$ in NSCLC samples, we used the calibration curves generated with RNA from Kelly and NCI-H2228 cells (see details in Materials and Methods). The curves were used to develop different predictive models, based on an inverse prediction approach [44], for the quantitative assessment of the $3^{\prime}$ and $5^{\prime}$ or only the $3^{\prime}$ portion of the $A L K$ transcript.

Initially, we compared the calibration curves prepared with Kelly cells in the presence or absence of pre-amplification. The two linear fits and associated residual sum of squares (RSS) of the data points relative to the $3^{\prime}$ and $5^{\prime} A L K$ portions, obtained with these two calibration curves, were comparable ( $3^{\prime}$ ALK - /+PreAMP, $R^{2}=0.99 / 0.99$, RSS $=1.17 / 1.23 ; 5^{\prime}$ ALK -/+PreAMP, $R^{2}=0.98 / 0.98$, RSS $=1.97 / 1.46$, Supplementary Figure S1A-B). Moreover, Cq improvements of $\sim 7.57 \pm$ 0.40 cycles for the $5^{\prime}$ and $\sim 7.38 \pm 0.35$ cycles for the $3^{\prime}$ portion of $A L K$ across all the data points of the dilution range were retained (Supplementary Table S4). To control for the balanced expression of the $3^{\prime}$ and $5^{\prime}$ portions of $A L K$, we calculated the difference between the $\triangle \mathrm{Cq}$ of the $3^{\prime}$ and of the $5^{\prime}$ portion of $A L K\left(\Delta \Delta \mathrm{Cq}_{3^{\prime}-5^{\prime} \mathrm{ALK}}=\Delta \mathrm{Cq}_{3^{\prime} \mathrm{ALK}}{ }^{-}\right.$ $\left.\Delta \mathrm{Cq}_{5^{\prime} \mathrm{ALK}}\right)$, relative to the endogenous controls, for each data point of the two calibration curves, in the presence and absence of pre-amplification. These $\Delta \Delta \mathrm{Cq}$ values are expected to remain stable across the dilution range in the case of balanced $3^{\prime} / 5^{\prime} A L K$ expressions. $\triangle \triangle \mathrm{Cq}$ values were more stable in the pre-amplified (range $=-0.36-0.03$; median $=-0.10 ; \mathrm{Q} 1=-0.15 ; \mathrm{Q} 3=-0.03)$ vs. not preamplified (range $=-0.91-0.38 ;$ median $=-0.30 ; \mathrm{Q} 1$ $=-0.41 ; \mathrm{Q} 3=-0.22$ ) calibration curve (Supplementary Figure S1C). Based on these results, pre-amplification was included in the generation of the calibration curve for NCI-H2228 cells, which behaved similarly to Kelly cells (Supplementary Figure S1D).

Next, we derived different fitting models using the Kelly and NCI-H2228 calibration curves, either by covering the entire $1-100 \%$ dilution range or by restricting the analysis to the $1-50 \%$ dilution range, where a better sensitivity of the assay is desirable. For the $3^{\prime}$ portion of $A L K$, we used both the Kelly and NCI-H2228 calibration curves, separately and pooled, as they are representative of both $A L K$ full-length expression and translocation. For the $5^{\prime}$ portion of $A L K$ we used only the curves obtained with Kelly cells. Overall, the different linear fits ( 6 for the $3^{\prime}$ and 2 for the 5' $A L K)$ were similar $\left(\mathrm{R}^{2}\right.$ range $=0.98-0.99$; Figure 2$)$. Parameters relative to the various derived algorithms (Supplementary Table S5) were then used to convert $A L K$ transcript expression measured in NSCLC samples by RT-qPCR into percentages of $3^{\prime}$ and/or $5^{\prime} A L K$ transcript positivity, as described in the following section.

\section{Validation of the ALK predictive model in a cohort of NSCLC patients}

To define the threshold value for $A L K$ positivity (abnormal $A L K$ expression) in NSCLC samples, we applied the different predictive models to a set of 20 lung FFPE non-pathological tissue samples. Based on the low basal levels of $3^{\prime} A L K$ and barely detectable levels of $5^{\prime} A L K$, measured in non-pathological lung tissues, the threshold value of $A L K$ positivity was set at $10 \%$ and $3 \%$ for the $3^{\prime}$ and $5^{\prime}$ portions, respectively (Supplementary Tables S6A-S6B).

Next, we applied the derived models to predict $A L K$ status in a cohort of 51 NSCLC FFPE samples, previously characterized by FISH for $A L K$ translocation, composed of 17 FISH positive and 34 FISH negative samples (Table 1). Of note, we obtained RT-qPCR data of adequate quality for all 51 FFPE NSCLC samples, as determined using the interquartile rule for outliers (see Materials and Methods and Supplementary Table S7). All models gave 100\% concordant binary predictions ( $A L K$ translocated or not translocated) for all the 51 FFPE NSCLC samples, with minor differences in the percentage of $3^{\prime}$ and/or 5' $A L K$ positivity (Supplementary Table S8). Moreover, models generated in the $1-50 \%$ dilution range exhibited narrower $95 \%$ confidence intervals for all the predicted percentages of $3^{\prime}$ and $5^{\prime} A L K$ positivity (including those $>50 \%$ ), compared with the models derived from the $1-100 \%$ dilution range $(\triangle \mathrm{Cq}$ data were simulated ranging from 0 to 15 , every 0.01 units, as shown in Figure $3 \mathrm{~A}-3 \mathrm{C}$ ). No significant differences were observed between the predictions obtained with the Kelly and the NCI-H2228 models in the $1-50 \%$ dilution range (Figure $3 \mathrm{~B}$ ). Thus, we used the algorithms generated with the Kelly model, which allows the concomitant detection of both the $3^{\prime}$ and $5^{\prime}$ portions of $A L K$, to predict $A L K$ status in the NSCLC cohort (Figure 3D).

Our model identified all the $17 A L K$ FISH-positive samples as translocated. Indeed, all these samples showed an elevated percentage of 3 ' positivity compared with the percentage of $5^{\prime}$ positivity, thereby confirming the presence of an unbalanced expression of the two $A L K$ regions as a consequence of a translocation event (Table 2). Among the 34 FISH-negative cases, 33 resulted not translocated by our method, while one sample was clearly detected as translocated (Case ID \#19, 3' ALK positivity of $58.6 \%$; $95 \%$ CI: 47-73.5), despite its scarce tumor cellularity $(5 \%$, Table 2$)$. This sample, with a marginal percentage of FISH positive nuclei $(10 \%$; Table 2), was ALK-positive by IHC analysis using the automated IHC Ventana assay, in agreement with our PCR assay. Thus, these data indicate that the discrepant FISH result was a false negative and, importantly, that our test reliably identifies $A L K$ translocations in specimens with limited tumor cellularity, as low as 5-10\% (Case ID \#13, $\# 15$ and \#19, Table 2). 
Table 1: Clinico-pathological characteristics of the NSCLC cohort composed of 51 surgical and 7 cytology specimens analyzed for $A L K$ expression

\begin{tabular}{|c|c|c|c|c|c|c|c|}
\hline $\begin{array}{l}\text { Case } \\
\text { ID }\end{array}$ & $\begin{array}{l}\text { Age } \\
\text { (yrs) }\end{array}$ & Sex & Histology & $\begin{array}{c}\text { EGFR/KRAS } \\
\text { Mutation }\end{array}$ & $\begin{array}{l}\text { Tumor Site } \\
\text { (Primary/ } \\
\text { Metastasis) }\end{array}$ & $\begin{array}{l}\text { Specimen } \\
\text { Analyzed }\end{array}$ & $\begin{array}{l}\text { FISH } \\
\text { ALK }\end{array}$ \\
\hline 1 & 54 & $F$ & ADK & NEG/NEG & Metastasis & Pleura & POS \\
\hline 2 & 65 & $F$ & $\mathrm{ADK}$ & NEG/NEG & Primary & Lung & POS \\
\hline 3 & 48 & $\mathrm{~F}$ & $\mathrm{ADK}$ & NEG/NEG & Metastasis & Pleura & POS \\
\hline 4 & 47 & $\mathrm{M}$ & ADK & $\mathrm{ND} / \mathrm{ND}$ & Metastasis & Lymph node & POS \\
\hline 5 & 81 & $\mathrm{~F}$ & $\mathrm{ADK}$ & ND/NEG & Primary & Lung & POS \\
\hline 6 & 66 & $\mathrm{M}$ & $\overline{\mathrm{ADK}}$ & NEG/NEG & Primary & Lung & POS \\
\hline 7 & 38 & $\mathrm{~F}$ & ADK & NEG/NEG & Primary & Lung & POS \\
\hline 8 & 58 & $\mathrm{M}$ & $\mathrm{ADK}$ & NEG/NEG & Metastasis & Lymph node & POS \\
\hline 9 & 38 & $\mathrm{~F}$ & $\mathrm{ADK}$ & NEG/NEG & Metastasis & Lymph node & POS \\
\hline 10 & 49 & F & $\mathrm{ADK}$ & NEG/NEG & Metastasis & Lymph node & POS \\
\hline 11 & 47 & $\mathrm{~F}$ & ADK & NEG/NEG & Metastasis & Pleura & POS \\
\hline 12 & 52 & $\mathrm{~F}$ & $\mathrm{ADK}$ & NEG/NEG & Primary & Lung & POS \\
\hline 13 & 61 & $\mathrm{M}$ & $\overline{\mathrm{ADK}}$ & NEG/NEG & Metastasis & Pleura & POS \\
\hline 14 & 51 & $F$ & ADK & NEG/NEG & Metastasis & Lymph node & POS \\
\hline 15 & 66 & $\mathrm{M}$ & ADK & NEG/NEG & Metastasis & Pleura & POS \\
\hline 16 & 36 & $\mathrm{~F}$ & ADK & NEG/NEG & Primary & Lung & POS \\
\hline 17 & 44 & $F$ & ADK & $\mathrm{ND} / \mathrm{ND}$ & Primary & Lung & POS \\
\hline 18 & 61 & $\mathrm{M}$ & ADK & POS/NEG & Metastasis & Pleura & NEG \\
\hline 19 & 54 & $F$ & ADK & NEG/NEG & Primary & Lung & NEG \\
\hline 20 & 70 & $\mathrm{M}$ & ADSK + NET & NEG/NEG & Primary & Lung & NEG \\
\hline 21 & 68 & $\mathrm{M}$ & $\mathrm{ADK}$ & POS/NEG & Primary & Lung & NEG \\
\hline 22 & 61 & $\mathrm{M}$ & ADK & NEG/POS & Primary & Lung & NEG \\
\hline 23 & 63 & $\mathrm{M}$ & ADK & NEG/NEG & Primary & Lung & NEG \\
\hline 24 & 56 & $\mathrm{~F}$ & $\mathrm{PC}$ & NEG/POS & Primary & Lung & NEG \\
\hline 25 & 65 & $F$ & ADK & NEG/POS & Primary & Lung & NEG \\
\hline 26 & 58 & $\mathrm{M}$ & $\overline{\mathrm{ADK}}$ & NEG/NEG & Primary & Lung & NEG \\
\hline 27 & 63 & $\mathrm{M}$ & ADK & NEG/POS & Primary & Lung & NEG \\
\hline 28 & 80 & $\mathrm{M}$ & $\mathrm{ADK}$ & NEG/POS & Primary & Lung & NEG \\
\hline 29 & 58 & $\mathrm{~F}$ & ADSK & NEG/NEG & Primary & Lung & NEG \\
\hline 30 & 49 & $\mathrm{M}$ & ADK & POS/NEG & Metastasis & Pleura & NEG \\
\hline 31 & 68 & $\mathrm{M}$ & ADK & NEG/ND & Primary & Lung & NEG \\
\hline 32 & 71 & $\mathrm{M}$ & $\overline{\mathrm{ADK}}$ & NEG/ND & Primary & Lung & $\overline{\mathrm{NEG}}$ \\
\hline 33 & 65 & $\mathrm{M}$ & $\mathrm{ADK}$ & NEG/NEG & Primary & Lung & NEG \\
\hline 34 & 50 & $\bar{F}$ & $\overline{A D K}$ & NEG/ND & Primary & Lung & NEG \\
\hline 35 & 53 & $M$ & ADK & NEG/POS & Primary & Lung & NEG \\
\hline 36 & 53 & $F$ & ADK & NEG/ND & Primary & Lung & NEG \\
\hline 37 & 59 & $\mathrm{M}$ & ADK & NEG/NEG & Primary & Lung & NEG \\
\hline 38 & 78 & $\mathrm{M}$ & ADSK & NEG/ND & Primary & Lung & NEG \\
\hline 39 & 68 & $\mathrm{~F}$ & ADK & NEG/ND & Primary & Lung & NEG \\
\hline 40 & 68 & $\mathrm{M}$ & $\mathrm{ADK}$ & NEG/NEG & Primary & Lung & NEG \\
\hline
\end{tabular}




\begin{tabular}{|c|c|c|c|c|c|c|c|}
\hline 41 & 60 & $\mathrm{M}$ & ADK & NEG/POS & Primary & Lung & NEG \\
\hline 42 & 59 & $\mathrm{M}$ & ADK & NEG/ND & Primary & Lung & NEG \\
\hline 43 & 61 & $\mathrm{~F}$ & ADK & NEG/ND & Primary & Lung & NEG \\
\hline 44 & 71 & $\mathrm{M}$ & ADK & NEG/POS & Metastasis & Pleura & NEG \\
\hline 45 & 62 & $\mathrm{~F}$ & ADK & NEG/POS & Primary & Lung & NEG \\
\hline 46 & 66 & $\mathrm{M}$ & ADK & NEG/POS & Metastasis & Pleura & NEG \\
\hline 47 & 46 & $\mathrm{~F}$ & SCC & POS/NEG & Metastasis & Parietal Pleura & NEG \\
\hline 48 & 63 & $\mathrm{M}$ & ADK & POS/NEG & Metastasis & Lymph node & NEG \\
\hline 49 & 73 & $\mathrm{~F}$ & ADK & NEG/NEG & Metastasis & Lymph node & NEG \\
\hline 50 & 72 & $\mathrm{M}$ & ADK & NEG/POS & Metastasis & Pleura & NEG \\
\hline 51 & 50 & $\mathrm{M}$ & ADK & NEG/POS & Primary & Lung & NEG \\
\hline 52 & 55 & $\mathrm{~F}$ & ADK & NEG/NEG & Metastasis & $\begin{array}{c}\text { Lymph node/ } \\
\text { Cytology }\end{array}$ & NEG \\
\hline 53 & 82 & $\mathrm{M}$ & ADK & NEG/NA & Metastasis & $\begin{array}{c}\text { Lymph node/ } \\
\text { Cytology }\end{array}$ & NEG \\
\hline 54 & 68 & $\mathrm{M}$ & ADK & NEG/POS & Metastasis & $\begin{array}{c}\text { Lymph node/ } \\
\text { Cytology }\end{array}$ & NEG \\
\hline 55 & 64 & $\mathrm{M}$ & ADK & NEG/NEG & Metastasis & $\begin{array}{c}\text { Lymph node/ } \\
\text { Cytology }\end{array}$ & NEG \\
\hline 56 & 63 & $\mathrm{M}$ & ADK & NEG/NA & Metastasis & $\begin{array}{c}\text { Lymph node/ } \\
\text { Cytology }\end{array}$ & NEG \\
\hline 58 & 75 & $\mathrm{M}$ & ADK & NEG/POS & Metastasis & $\begin{array}{c}\text { Lymph node/ } \\
\text { Cytology }\end{array}$ & POS \\
\hline
\end{tabular}

Case IDs \#1-51 refer to surgical specimens and Case IDs \#52-58 refer to cytology specimens obtained by EBUS. Age at surgery is indicated (yrs); F, female; M, male; ADK, adenocarcinoma; ADSK, adenosquamous cell carcinoma; ADSK + NET, adenosquamous cell carcinoma + neuroendocrine; SCC, squamous; PC, pleomorphic carcinoma of the lung; EGFR, epidermal growth factor receptor; KRAS, Kirsten rat sarcoma viral oncogene homolog; POS, positive; NEG, negative; ND, not determined or missing data; ALK, anaplastic lymphoma kinase; FISH, fluorescent in situ hybridization.

Among the 33 tumors identified as not translocated by our PCR assay, two exhibited a level of $3^{\prime}$ positivity significantly above the $10 \%$ cut-off (Case ID \#20,13.5\%; Case ID \#25, 15.5\%, Table 2). Both these samples, however, showed percentages of $5^{\prime}$ positivity comparable to the $3^{\prime}$ portion (Table 2), suggesting that they did not harbor an $A L K$ translocation, but rather expressed low/ moderate levels of normal $A L K$ transcripts. Together, these results showed that our diagnostic model reached a sensitivity, specificity and accuracy of $100 \%, 97 \%$ and 98\%, respectively, compared with FISH.

To evaluate whether our predictive model was accurate when using low quantities of input RNA, representative FFPE NSCLC samples (21 in total), covering a wide range of $A L K$ positivity, were processed using 25 and $10 \mathrm{ng}$ of total RNA instead of $100 \mathrm{ng}$. The predictions relative to the three different RNA quantities $(100,25$ and $10 \mathrm{ng})$ were $100 \%$ concordant, indicating that our model reliably detects $A L K$ status in FFPE NSCLC samples also when the input RNA is scarce (Table 3).

Finally, we analyzed 7 cytological FFPE samples (5 $A L K$ FISH-negative and $2 A L K$ FISH-positive), obtained with the minimally invasive endobronchial ultrasoundguided transbronchial needle aspiration (EBUS-TBNA) procedure, using $10 \mathrm{ng}$ input RNA (Table 1). Our assay correctly identified all the 5 FISH-negative cases and one of the two FISH-positive cases (Case ID \#58, with $38 \%$ of FISH positive nuclei; Table 4). Notably, the one discordant case (Case ID \#57, with a borderline $20 \%$ of FISH-positive nuclei) was confirmed to be negative by subsequent IHC analysis.

In summary, our diagnostic model reached a sensitivity, specificity and accuracy of $95 \%, 97 \%$ and $97 \%$, respectively, compared with FISH on a total of 58 FFPE NSCLC samples (51 surgical and 7 cytology specimens) (Figure 4). Notably, the two discrepant cases (one surgical 

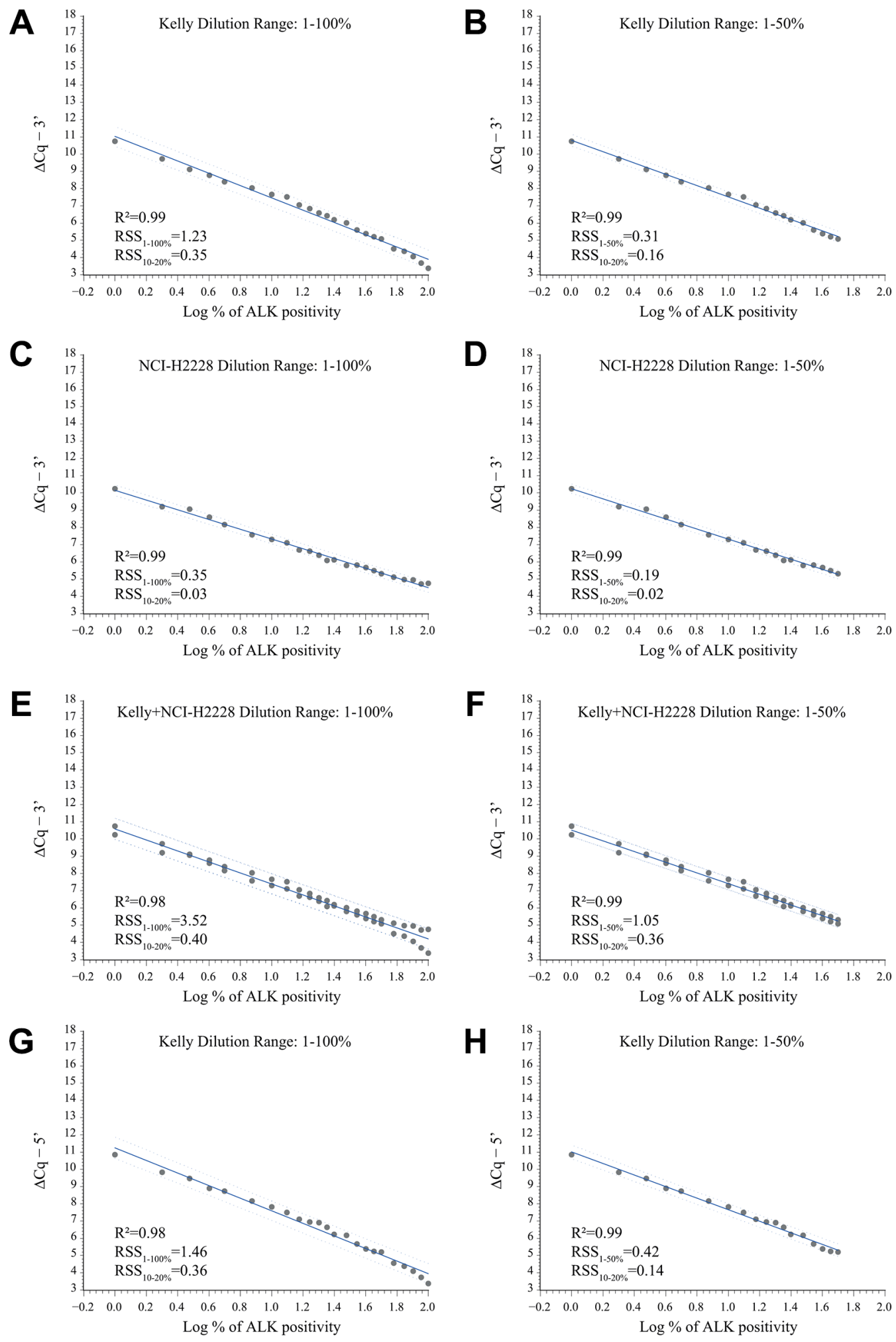

Figure 2: Development of various ALK models using external calibration curves. (A-F) Correlation plots of the expression values (grey dots) of the $3^{\prime}$ portion of $A L K$ relative to the $1-100 \%$ and the $1-50 \%$ dilution range in Kelly (A and B), NCI-H2228 (C and D), and pooled Kelly + NCI-H2228 (E and F) calibration curves. (G-H) Correlation plots of the expression values (grey dots) of the 5' portion of $A L K$ relative to the $1-100 \%(\mathrm{G})$ or the $1-50 \%(\mathrm{H})$ dilution range in the Kelly calibration curves. For all curves, linear fit (solid blue line) and $95 \%$ prediction limits (dashed blue line) are reported. Relative expression values of the $3^{\prime}\left(\Delta \mathrm{Cq}^{-} 3^{\prime}\right)$ or the $5^{\prime}\left(\Delta \mathrm{Cq}-5^{\prime}\right)$ portion of $A L K$ normalized to internal controls $\left(\Delta \mathrm{Cq}=\mathrm{Cq}_{\mathrm{ALK}}\right.$ - average $\left.\mathrm{Cq}_{\mathrm{RFF}}\right)$ by known percentage (log-transformed, base 10, Log \%) of total RNA of $A L K$ positive cells in the different calibration curves are indicated. $\mathrm{R}^{2}$, coefficient of determination; RSS, residual sum of squares relative to the $1-100 \%\left(\mathrm{RSS}_{1-100 \%}\right)$, the $1-50 \%\left(\mathrm{RSS}_{1-50 \%}\right)$ and the $10-20 \%\left(\mathrm{RSS}_{10-20 \%}\right)$ dilution series, are shown. 
Table 2: Accuracy of the PCR-based predictive model in the assessment of ALK status in the 51 NSCLC cohort

\begin{tabular}{|c|c|c|c|c|c|c|c|c|}
\hline \multirow[t]{2}{*}{$\begin{array}{l}\text { Case } \\
\text { ID }\end{array}$} & \multicolumn{2}{|r|}{ FISH } & \multicolumn{3}{|c|}{$\begin{array}{l}\text { RT-qPCR Model - Kelly (1-50\%) } \\
100 \text { ng RNA }\end{array}$} & \multirow{2}{*}{$\begin{array}{c}\text { Tumor } \\
\text { Cell } \\
\text { Content } \\
(\%)\end{array}$} & \multirow{2}{*}{$\begin{array}{l}\text { Tumor Site } \\
\text { (Primary/ } \\
\text { Metastasis) }\end{array}$} & \multirow[t]{2}{*}{$\begin{array}{l}\text { Specimen } \\
\text { Analyzed }\end{array}$} \\
\hline & $\begin{array}{l}\text { ALK } \\
\text { score }\end{array}$ & $\begin{array}{c}\text { Positive } \\
\text { Nuclei }(\%)\end{array}$ & $\begin{array}{c}A L K \\
\text { Status }\end{array}$ & $\begin{array}{c}3^{\prime} A L K \\
\text { Positivity }(\%)\end{array}$ & $\begin{array}{c}5^{\prime} A L K \\
\text { Positivity }(\%)\end{array}$ & & & \\
\hline 1 & POS & 90 & $\mathrm{~T}$ & $82.6(66.0-100)$ & 0 & 30 & Metastasis & Pleura \\
\hline 2 & POS & 64 & $\mathrm{~T}$ & $100(100-100)$ & 0 & 60 & Primary & Lung \\
\hline 3 & POS & 87 & $\mathrm{~T}$ & $100(100-100)$ & 0 & 60 & Metastasis & Pleura \\
\hline 4 & POS & 61 & $\mathrm{~T}$ & $100(81.1-100)$ & 0 & 80 & Metastasis & Lymph node \\
\hline 5 & POS & 55 & $\mathrm{~T}$ & $100(100-100)$ & 0 & 80 & Primary & Lung \\
\hline 6 & POS & 61 & $\mathrm{~T}$ & $100(98.4-100)$ & 0 & 70 & Primary & Lung \\
\hline 7 & POS & 70 & $\mathrm{~T}$ & $100(100-100)$ & 0 & 60 & Primary & Lung \\
\hline 8 & POS & 50 & $\mathrm{~T}$ & $100(100-100)$ & 0 & 60 & Metastasis & Lymph node \\
\hline 9 & POS & 50 & $\mathrm{~T}$ & $100(100-100)$ & 0 & 60 & Metastasis & Lymph node \\
\hline 10 & POS & 53 & $\mathrm{~T}$ & $100(100-100)$ & 0 & 70 & Metastasis & Lymph node \\
\hline 11 & POS & 31 & $\mathrm{~T}$ & $75.4(60.3-95.0)$ & 0 & 20 & Metastasis & Pleura \\
\hline 12 & POS & 35 & $\mathrm{~T}$ & $100(100-100)$ & 0 & 30 & Primary & Lung \\
\hline 13 & POS & 23 & $\mathrm{~T}$ & $97.7(77.8-100)$ & 0 & 10 & Metastasis & Pleura \\
\hline 14 & POS & 24 & $\mathrm{~T}$ & $91.1(72.6-100)$ & 0 & 40 & Metastasis & Lymph node \\
\hline 15 & POS & 32 & $\mathrm{~T}$ & $55.8(44.8-69.9)$ & $8.7(6.8-11.0)$ & 5 & Metastasis & Pleura \\
\hline 16 & POS & 24 & $\mathrm{~T}$ & $100(100-100)$ & 0 & 50 & Primary & Lung \\
\hline 17 & POS & 25 & $\mathrm{~T}$ & $100(100-100)$ & 0 & 60 & Primary & Lung \\
\hline 18 & $\mathrm{NEG}$ & 8 & NT & 0 & 0 & 70 & Metastasis & Pleura \\
\hline 19 & $\mathrm{NEG}$ & 10 & $\mathrm{~T}$ & $58.6(47.0-73.5)$ & 0 & 5 & Primary & Lung \\
\hline 20 & $\mathrm{NEG}$ & 3 & NT & $13.5(10.9-16.6)$ & $11.0(8.6-14.0)$ & 80 & Primary & Lung \\
\hline 21 & $\mathrm{NEG}$ & 0 & NT & $4.6(3.7-5.7)$ & $1.2(0.9-1.5)$ & 70 & Primary & Lung \\
\hline 22 & NEG & 8 & NT & $6.2(5.0-7.7)$ & 0 & 60 & Primary & Lung \\
\hline 23 & $\mathrm{NEG}$ & 2 & NT & $3.8(3.1-4.8)$ & 0 & 80 & Primary & Lung \\
\hline 24 & $\mathrm{NEG}$ & 5 & NT & $0.8(0.6-1.0)$ & 0 & 60 & Primary & Lung \\
\hline 25 & NEG & 11 & NT & $15.5(12.5-19.2)$ & $24.4(19.2-31.3)$ & 50 & Primary & Lung \\
\hline 26 & $\mathrm{NEG}$ & 0 & NT & $5.5(4.4-6.8)$ & 0 & 30 & Primary & Lung \\
\hline 27 & NEG & 5 & NT & $4.4(3.6-5.5)$ & $4.9(3.8-6.3)$ & 30 & Primary & Lung \\
\hline 28 & $\mathrm{NEG}$ & 0 & NT & $3.3(2.7-4.1)$ & 0 & 60 & Primary & Lung \\
\hline 29 & NEG & 1 & NT & $1.8(1.4-2.2)$ & 0 & 80 & Primary & Lung \\
\hline 30 & NEG & 4 & NT & 0 & 0 & 70 & Metastasis & Pleura \\
\hline 31 & NEG & 3 & NT & $2.0(1.6-2.5)$ & 0 & 80 & Primary & Lung \\
\hline 32 & NEG & 3 & NT & $5.4(4.4-6.7)$ & $2.0(1.5-2.5)$ & 80 & Primary & Lung \\
\hline 33 & $\mathrm{NEG}$ & 0 & NT & 0 & 0 & 80 & Primary & Lung \\
\hline 34 & $\mathrm{NEG}$ & 4 & NT & $8.8(7.1-10.9)$ & $13.1(10.3-16.7)$ & 90 & Primary & Lung \\
\hline 35 & NEG & 0 & NT & 0 & 0 & 60 & Primary & Lung \\
\hline 36 & $\mathrm{NEG}$ & 0 & NT & 0 & 0 & 60 & Primary & Lung \\
\hline 37 & NEG & 5 & NT & 0 & 0 & 80 & Primary & Lung \\
\hline
\end{tabular}




\begin{tabular}{|c|c|c|c|c|c|c|c|c|}
\hline 38 & NEG & 5 & NT & 0 & 0 & 70 & Primary & Lung \\
\hline 39 & NEG & 2 & NT & $4.3(3.4-5.3)$ & $2.4(1.9-3.1)$ & 70 & Primary & Lung \\
\hline 40 & NEG & 2 & NT & $2.9(2.3-3.6)$ & 0 & 60 & Primary & Lung \\
\hline 41 & NEG & 4 & NT & $1.7(1.4-2.1)$ & 0 & 60 & Primary & Lung \\
\hline 42 & NEG & 13 & NT & 0 & 0 & 40 & Primary & Lung \\
\hline 43 & NEG & 6 & NT & 0 & 0 & 80 & Primary & Lung \\
\hline 44 & NEG & 13 & NT & $0.9(0.7-1.1)$ & 0 & 80 & Metastasis & Pleura \\
\hline 45 & NEG & 1 & NT & 0 & 0 & 40 & Primary & Lung \\
\hline 46 & NEG & 3 & NT & $3.6(2.9-4.4)$ & $6.5(5.1-8.3)$ & 5 & Metastasis & Pleura \\
\hline 47 & NEG & 4 & NT & $0.9(0.7-1.1)$ & 0 & 70 & Metastasis & $\begin{array}{c}\text { Parietal } \\
\text { Pleura }\end{array}$ \\
\hline 48 & NEG & 2 & NT & $6.0(4.8-7.4)$ & 0 & 40 & Metastasis & Lymph node \\
\hline 49 & NEG & 1 & NT & $1.8(1.4-2.2)$ & 0 & 40 & Metastasis & Lymph node \\
\hline 50 & NEG & 4 & NT & 0 & 0 & 20 & Metastasis & Pleura \\
\hline 51 & NEG & 1 & NT & 0 & 0 & 60 & Primary & Lung \\
\hline Kelly & - & - & NT & $100(100-100)$ & $100(100-100)$ & - & & - \\
\hline NCI-H2228 & - & - & T & $71.8(57.4-90.3)$ & 0 & - & - & - \\
\hline A549 & - & - & NT & 0 & 0 & - & - & - \\
\hline
\end{tabular}

Binary $A L K$ status by FISH analysis is indicated as positive (POS, $\geq 15 \%$ of positive nuclei) or negative (NEG, $<15 \%$ of positive nuclei). Percentage (\%) of FISH positive nuclei with separated green and red signals or single red signals (translocation and deletion of the $A L K 5^{\prime}$ portion, respectively) are reported when available. Binary $A L K$ status determined by the PCR-based model analysis is indicated as Translocated (T) or Not Translocated (NT) based on the predicted percentage of $3^{\prime}$ and $5^{\prime} A L K$ positivity measured in each FFPE NSCLC sample (positivity cut-off value for the $3^{\prime}$ and $5^{\prime} A L K$ portions were $10 \%$ and $3 \%$, respectively). Predicted percentages of $3^{\prime}$ and $5^{\prime} A L K$ positive RNA present in FFPE NSCLC samples are reported along with the $95 \%$ confidence intervals in brackets. These values were calculated from the data obtained in the RT-qPCR analysis by the ALK inverse prediction models obtained from the Kelly calibration curves for the $3^{\prime}$ and $5^{\prime}$ portions of $A L K$. The model was derived considering the $1-50 \%$ dilution series of the external calibration curves. $A L K$ transcript expression was measured using the PCR protocol optimized for FFPE samples starting from $100 \mathrm{ng}$ of input RNA. The percentage (\%) of tumor cell content is also indicated for each sample. ALK, anaplastic lymphoma kinase; FISH, fluorescence in-situ hybridization; RT-qPCR, quantitative reverse transcription-polymerase chain reaction.

and one cytological) were confirmed as positive by IHC, thus raising the accuracy of our test to $100 \%$.

\section{DISCUSSION}

The discovery of effective ALK-targeted therapies for the treatment of NSCLC demands that we improve our ability to identify patients eligible for treatment. The FDAapproved break-apart FISH assay represented the gold standard for the detection of $A L K$ rearrangements during the crizotinib trials. However, given the difficulty in signal interpretation [45], the FISH assay yields erroneous results $[18,21,23,46,47]$. The recently approved Ventana ALK IHC (D5F3) CDx assay is a viable alternative to FISH. Although this IHC assay provides a simple digital reading of ALK status to limit inter-observer variability, a qualified pathologist is needed to grade the result and proprietary stainer and kits are required. Therefore, more quantitative, objective, and open source methodologies could find widespread application in clinical laboratories and help to resolve discrepant cases and/or equivocal results.

Quantitative PCR is a reliable and extremely sensitive technique for the measurement of clinical biomarkers. Optimal PCR-based ALK assays in clinical practice should be i) versatile (able to detect any ALK alteration), ii) accurate (especially when using low quantity, poor quality and low tumor cellularity FFPE biological samples), iii) user-friendly (implementable in routine clinical labs), and iv) cost-effective (particularly relevant for the screening of large, low-incidence populations). Our simple RT-qPCR-based predictive model fulfills these requirements. The combination of a simple inverse prediction model with an optimized RTqPCR protocol showed that our ALK test was superior to the break-apart FISH assay in a cohort of 58 FFPE NSCLC cases, composed of 51 surgical and 7 cytology 
specimens. Overall, our diagnostic model reached a sensitivity, specificity and accuracy of 95\%, 97\% and 97\%, respectively, compared with FISH (Tables 2 and 4, Figure 4), and further validation on a larger cohort is now merited. Notably, the accuracy of our test rose to $100 \%$ when the FISH false-negative surgical sample and the FISH false-positive cytology sample were reclassified as ALK-positive and ALK-negative, respectively, according to IHC (Figure 4). Our predictive test also provided high percentages of $3^{\prime} A L K$ positivity in samples with borderline percentages of FISH-positive nuclei (range $=10-35 \%$ ), demonstrating superior sensitivity (Table 2 and Table 3). Additionally, our assay was accurate when using as little as $10 \mathrm{ng}$ of input RNA, also in samples with low tumor cellularity (5-10\%, Tables 2 and 3$)$ and in cytological specimens (Table 4), which is frequently the only clinical material available in patients with advanced lung cancer. Notably, in a couple of cases (Case ID \#20 and \#25, Table 2), our test detected overexpression of fulllength $A L K$, in the absence of $A L K$ translocation (Table 2). Whether this higher expression identifies a small fraction of lung cancers sensitive to ALK inhibitors remains to be established. In addition, by targeting exons $27-28$ in the $3^{\prime}$ portion of $A L K$, our assay is able to detect also the recently identified $A L K$ isoforms (though rare in lung cancer), encompassing exons 20-29 [48].

Our test offers several advantages over published [39-43] assays assessing the unbalanced expression of the $3^{\prime}$ and 5' portion of $A L K$ transcript: i) it requires at least 5-10 times less input RNA; ii) it does not require expensive and proprietary technologies or specialist expertise (unlike NanoString and/or NGS platforms), and

\section{A $\quad$ B $\quad$ C}

Dilution Range: $1-100 \%$

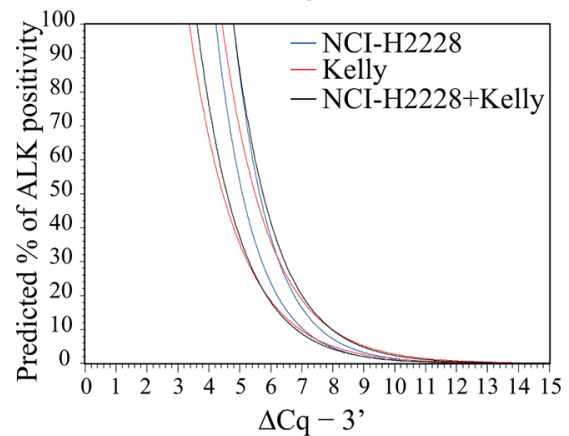

Dilution Range: $1-50 \%$

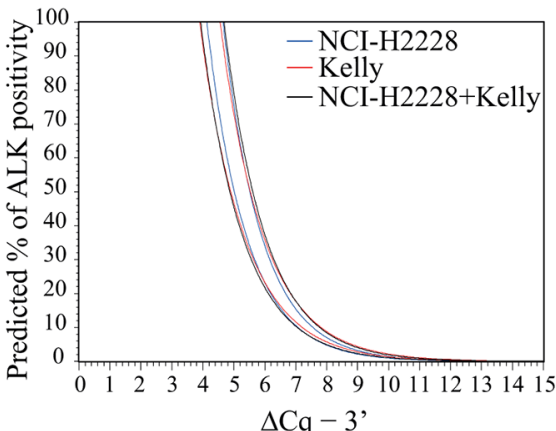

Kelly

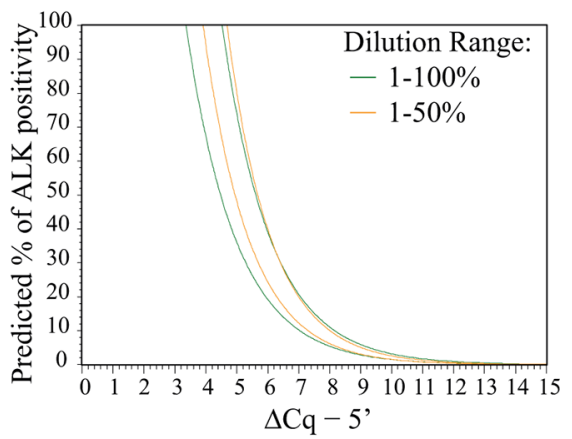

D

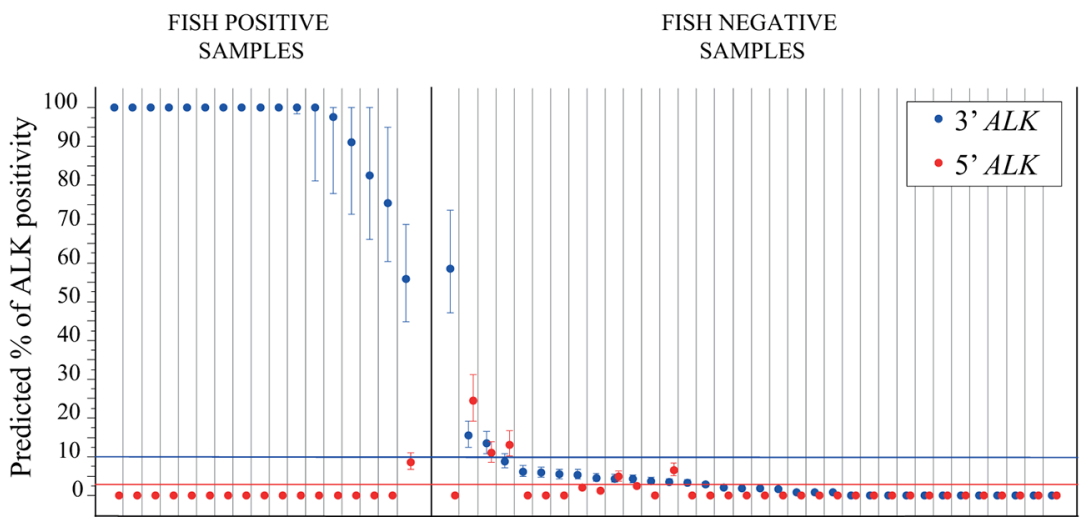

Figure 3: Comparison of the confidence bands in the different models and validation of the Kelly 1-50\% ALK predictive model using FFPE NSCLC samples. (A-B) Confidence bands at $95 \%$ for predicted percentages of $3^{\prime} A L K$ positivity relative to the calibration curves in the $1-100 \%$ (A) or the $1-50 \%$ (B) range with NCI-H2228 (blue lines), Kelly (red lines) and Kelly + NCI-H2228 (black lines) for the $A L K 3^{\prime}$ portion. (C) Confidence bands at $95 \%$ for predicted percentages of $5^{\prime} A L K$ positivity specific to the Kelly calibration curves in the $1-100 \%$ (green line) or the $1-50 \%$ (orange line) range. $\Delta$ Cq data were simulated ranging from 0 to 15 , every 0.01 units. Estimates were obtained through inverse prediction models considering the indicated calibration curves and dilution series. (D) Predicted percentage (and 95\% confidence bars) of 3' (blue dots) and 5' (red dots) ALK portions for the 17 FISH-positive and 34 FISHnegative NSCLC samples. Blue and red lines indicate the threshold for the 3' (10\%) and 5' (3\%) ALK positivity, respectively. 


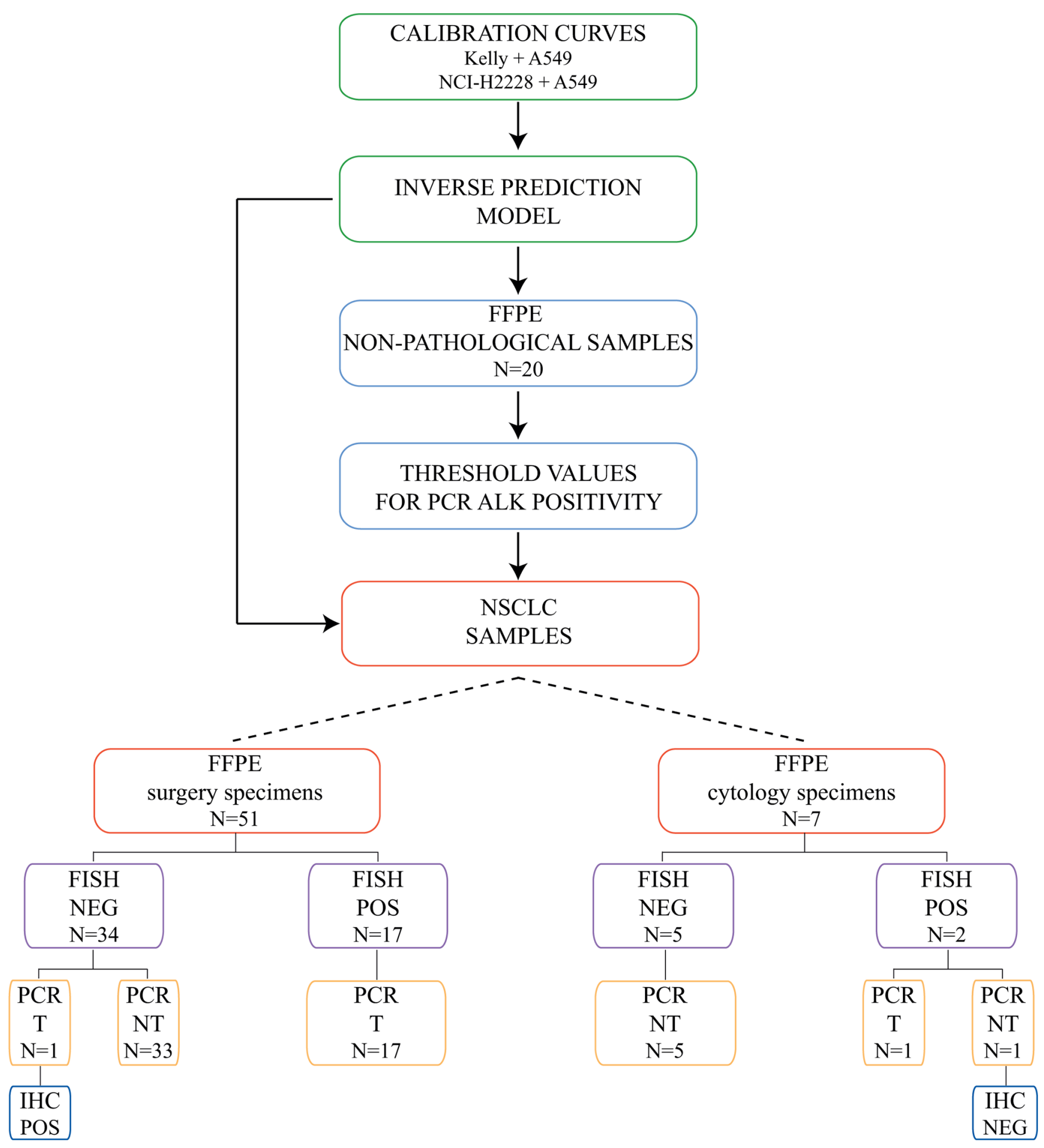

Figure 4: Study design for the development of the RT-qPCR-based prediction model and the validation on 58 FFPE NSCLC tissue specimens. Schematic representation of the analysis of $A L K$ status in the NSCLC cohort. The cohort was composed of 51 surgical and 7 cytology FFPE NSCLC specimens (see Table 1). Binary $A L K$ status by FISH analysis is indicated as positive (POS, $\geq 15 \%$ of positive nuclei) or negative (NEG, $<15 \%$ of positive nuclei). Binary $A L K$ status determined by the PCR-based model analysis is indicated as Translocated (T) or Not Translocated (NT) based on the predicted percentage of 3' and 5' ALK positivity (cut-off values for 3' and $5^{\prime} A L K$ portions were $10 \%$ and $3 \%$, respectively). Binary $A L K$ status by IHC is indicated as positive (POS) or negative (NEG) based on the presence or lack of a strong granular cytoplasmic staining in tumor cells, respectively. 
Table 3: Accuracy of $A L K$ status prediction in a selected subset of 21 NSCLC samples using 100, 25 and $10 \mathrm{ng}$ of input RNA

\begin{tabular}{|c|c|c|c|c|c|c|c|c|c|c|c|c|}
\hline \multirow{3}{*}{$\begin{array}{l}\text { Case } \\
\text { ID }\end{array}$} & \multirow{2}{*}{\multicolumn{2}{|c|}{ FISH }} & \multicolumn{9}{|c|}{ RT-qPCR Model - Kelly (1-50\%) } & \multirow{3}{*}{$\begin{array}{l}\text { Tumor } \\
\text { Cell } \\
\text { Content } \\
(\%)\end{array}$} \\
\hline & & & \multicolumn{3}{|c|}{100 ng RNA } & \multicolumn{3}{|c|}{25 ng RNA } & \multicolumn{3}{|c|}{10 ng RNA } & \\
\hline & $\begin{array}{l}\text { ALK } \\
\text { Score }\end{array}$ & $\begin{array}{c}\text { Positive } \\
\text { Nuclei } \\
(\%)\end{array}$ & $\begin{array}{c}A L K \\
\text { Status }\end{array}$ & $\begin{array}{c}3^{\prime} A L K \\
\text { Positivity } \\
(\%)\end{array}$ & $\begin{array}{c}5^{\prime} A L K \\
\text { Positivity } \\
\text { (\%) }\end{array}$ & $\begin{array}{c}A L K \\
\text { Status }\end{array}$ & $\begin{array}{c}3^{\prime} A L K \\
\text { Positivity } \\
\text { (\%) }\end{array}$ & $\begin{array}{c}5^{\prime} A L K \\
\text { Positivity } \\
(\%)\end{array}$ & $\begin{array}{c}A L K \\
\text { Status }\end{array}$ & $\begin{array}{c}3^{\prime} A L K \\
\text { Positivity } \\
(\%) \\
\end{array}$ & $\begin{array}{c}5^{\prime} A L K \\
\text { Positivity } \\
(\%)\end{array}$ & \\
\hline 5 & POS & 55 & $\mathrm{~T}$ & $100(100-100)$ & 0 & $\mathrm{~T}$ & $100(100-100)$ & 0 & $\mathrm{~T}$ & $100(100-100)$ & 0 & 80 \\
\hline 6 & POS & 61 & $\mathrm{~T}$ & $100(98.4-100)$ & 0 & $\mathrm{~T}$ & $100(82.8-100)$ & 0 & $\mathrm{~T}$ & $96.4(76.8-100)$ & 0 & 70 \\
\hline 7 & POS & 70 & $\mathrm{~T}$ & $100(100-100)$ & 0 & $\mathrm{~T}$ & $100(100-100)$ & 0 & $\mathrm{~T}$ & $100(100-100)$ & 0 & 60 \\
\hline 8 & POS & 50 & $\mathrm{~T}$ & $100(100-100)$ & 0 & $\mathrm{~T}$ & $100(100-100)$ & 0 & $\mathrm{~T}$ & $100(100-100)$ & 0 & 60 \\
\hline 9 & POS & 50 & $\mathrm{~T}$ & $100(100-100)$ & 0 & $\mathrm{~T}$ & $100(100-100)$ & 0 & $\mathrm{~T}$ & $100(100-100)$ & 0 & 60 \\
\hline 11 & POS & 31 & $\mathrm{~T}$ & $75.4(60.3-95.0)$ & 0 & $\mathrm{~T}$ & $83.8(66.9-100)$ & 0 & $\mathrm{~T}$ & $100(100-100)$ & 0 & 20 \\
\hline 13 & POS & 23 & $\mathrm{~T}$ & $97.7(77.8-100)$ & 0 & $\mathrm{~T}$ & $79.7(63.7-100)$ & 0 & $\mathrm{~T}$ & $85.5(68.3-100)$ & 0 & 10 \\
\hline 16 & POS & 24 & $\mathrm{~T}$ & $100(100-100)$ & 0 & $\mathrm{~T}$ & $100(100-100)$ & 0 & $\mathrm{~T}$ & $100(100-100)$ & 0 & 50 \\
\hline 19 & NEG & 10 & $\mathrm{~T}$ & $58.6(47.0-73.5)$ & 0 & $\mathrm{~T}$ & $48.5(39.0 .-60.7)$ & 0 & $\mathrm{~T}$ & $63.7(51.1-80.0)$ & 0 & 5 \\
\hline 20 & NEG & 3 & NT & $13.5(10.9-16.6)$ & $\begin{array}{c}11.0 \\
(8.6-14.0)\end{array}$ & NT & $10.3(8.3-12.7)$ & $\begin{array}{c}11.6 \\
(9.1-14.8)\end{array}$ & NT & $8.9(7.2-11.0)$ & $\begin{array}{c}9.0 \\
(7.0-11.4)\end{array}$ & 80 \\
\hline 21 & NEG & 0 & NT & $4.6(3.7-5.7)$ & $\begin{array}{c}1.2 \\
(0.9-1.5) \\
\end{array}$ & NT & $5.1(4.1-6.3)$ & $\begin{array}{c}1.3 \\
(1.0-1.6) \\
\end{array}$ & NT & $5.4(4.4-6.7)$ & $\begin{array}{c}3.0 \\
(2.3-3.9) \\
\end{array}$ & 70 \\
\hline 22 & NEG & 8 & NT & $6.2(5.0-7.7)$ & 0 & NT & $5.2(4.2-6.5)$ & 0 & NT & $4.3(3.5-5.4)$ & 0 & 60 \\
\hline 23 & NEG & 2 & NT & $3.8(3.1-4.8)$ & 0 & NT & $3.5(2.8-4.3)$ & 0 & NT & $4.7(3.8-5.9)$ & 0 & 80 \\
\hline 26 & NEG & 0 & NT & $5.5(4.4-6.8)$ & 0 & NT & $4.4(3.6-5.5)$ & 0 & NT & $7.6(6.2-9.4)$ & 0 & 30 \\
\hline 38 & NEG & 5 & NT & 0 & 0 & NT & 0 & 0 & NT & 0 & 0 & 70 \\
\hline 39 & NEG & 2 & NT & $4.3(3.4-5.3)$ & $\begin{array}{c}2.4 \\
(1.9-3.1) \\
\end{array}$ & NT & $6.4(5.1-7.9)$ & $\begin{array}{c}4.4 \\
(3.4-5.6) \\
\end{array}$ & NT & $8.1(6.5-10.0)$ & 0 & 70 \\
\hline 43 & NEG & 6 & NT & 0 & 0 & NT & 0 & 0 & NT & 0 & 0 & 80 \\
\hline 44 & NEG & 13 & NT & $0.9(0.7-1.1)$ & 0 & NT & 0 & 0 & NT & 0 & 0 & 80 \\
\hline 48 & NEG & 2 & NT & $6.0(4.8-7.4)$ & 0 & NT & $5.1(4.1-6.3)$ & 0 & NT & 0 & 0 & 40 \\
\hline 49 & NEG & 1 & NT & $1.8(1.4-2.2)$ & 0 & NT & $2.6(2.1-3.2)$ & 0 & NT & 0 & 0 & 40 \\
\hline 51 & NEG & 1 & NT & 0 & 0 & NT & 0 & 0 & NT & 0 & 0 & 60 \\
\hline
\end{tabular}

Binary $A L K$ status by FISH analysis is indicated as positive (POS, $\geq 15 \%$ of positive nuclei) or negative (NEG, $<15 \%$ of positive nuclei). Percentage (\%) of FISH positive nuclei with separated green and red signals or single red signals (translocation and deletion of the $A L K 5^{\prime}$ portion, respectively) are reported when available. Binary $A L K$ status determined by the PCR-based model analysis is indicated as Translocated (T) or Not Translocated (NT) based on the predicted percentage of 3' and 5' ALK positivity measured in each FFPE NSCLC sample using 100, 25 or 10 ng of RNA input (positivity cut-off values for the 3' and $5^{\prime} A L K$ portions were $10 \%$ and 3\%, respectively). Predicted percentages of $3^{\prime}$ and $5^{\prime} A L K$ positive RNA present in FFPE NSCLC samples are reported along with $95 \%$ confidence intervals in brackets. These values were calculated from the data obtained in the RT-qPCR analysis by the ALK inverse prediction models obtained from the Kelly calibration curves for the 3' and $5^{\prime}$ portions of $A L K$. The model was derived considering the $1-50 \%$ dilution series of the external calibration curves. The percentage (\%) of tumor cell content is also indicated for each sample. ALK, anaplastic lymphoma kinase; FISH, fluorescence in situ hybridization; RT-qPCR, quantitative reverse transcription-polymerase chain reaction.

iii) it provides a quantitative assessment of $3^{\prime}$ and $5^{\prime} A L K$ mRNA positivity. Unlike traditional comparative $(\Delta \Delta \mathrm{Cq})$ and/or $3^{\prime} / 5^{\prime}$ ratio methods derived thereof, our model provides confidence intervals for each point prediction. These interval estimates, by identifying the range of possible true values of the point prediction, will increase clinicians' confidence about the prediction score and help guide them in therapy decision-making.

Novel multiplex NGS assays represent attractive diagnostic tools for the detection of clinically relevant genomic alterations associated with solid tumors including
$A L K$ translocations [36, 49]. An extended comparative analysis of our predictive model $v s$. emerging NGS assays, employing large NSCLC cohorts, and technically challenging FFPE specimens is warranted. However, our results clearly show that our PCR-based ALK test is highly accurate in surgical as well as cytological specimens. Therefore, our diagnostic assay not only can be employed as a confirmatory test of FISH and/or IHC results and to resolve equivocal FISH and/or IHC results, but can also be used as a first-line diagnostic tool for the rapid, efficacious and convenient screening of large patient populations. 
Table 4: Accuracy of $A L K$ status prediction in the 7 cytology specimens using $10 \mathrm{ng}$ of input RNA

\begin{tabular}{|c|c|c|c|c|c|c|}
\hline \multirow{2}{*}{$\begin{array}{l}\text { Case } \\
\text { ID }\end{array}$} & \multicolumn{2}{|c|}{ FISH } & \multicolumn{3}{|c|}{ RT-qPCR Model - Kelly (1-50\%) - 10 ng RNA } & \multirow{2}{*}{$\begin{array}{r}\text { Tumor Cell } \\
\text { Content }(\%)\end{array}$} \\
\hline & $\begin{array}{l}\text { ALK } \\
\text { Score }\end{array}$ & $\begin{array}{c}\text { Positive } \\
\text { Nuclei (\%) }\end{array}$ & $\begin{array}{c}A L K \\
\text { Status }\end{array}$ & $\begin{array}{c}3^{\prime} A L K \\
\text { Positivity (\%) }\end{array}$ & $\begin{array}{c}5^{\prime} A L K \\
\text { Positivity (\%) }\end{array}$ & \\
\hline 52 & NEG & 11 & NT & 0 & 0 & 60 \\
\hline 53 & NEG & 9 & NT & 0 & 0 & 80 \\
\hline 54 & NEG & 9 & NT & 0 & 0 & 30 \\
\hline 55 & NEG & 12 & NT & 0 & 0 & 50 \\
\hline 56 & NEG & 9 & NT & 0 & $14.6(11.5-18.6)$ & 40 \\
\hline 57 & POS & 20 & NT & 0 & 0 & 70 \\
\hline 58 & POS & 38 & $\mathrm{~T}$ & $40.4(32.5-50.4)$ & 0 & 70 \\
\hline
\end{tabular}

Binary $A L K$ status by FISH analysis is indicated as positive (POS, $\geq 15 \%$ of positive nuclei) or negative (NEG, $<15 \%$ of positive nuclei). Percentage (\%) of FISH positive nuclei with separated green and red signals or single red signals (translocation and deletion of the $A L K 5^{\prime}$ portion, respectively) are reported. Binary $A L K$ status determined by the PCR-based model analysis is indicated as Translocated (T) or Not Translocated (NT) based on the predicted percentage of $3^{\prime}$ and $5^{\prime}$ $A L K$ positivity measured in each cytology sample using $10 \mathrm{ng}$ of RNA input (positivity cut-off values for the $3^{\prime}$ and $5^{\prime} A L K$ portions were $10 \%$ and $3 \%$, respectively). Predicted percentages of $3^{\prime}$ and $5^{\prime} A L K$ positive RNA present in FFPE NSCLC samples are reported along with $95 \%$ confidence intervals in brackets. These values were calculated from the data obtained in the RT-qPCR analysis by the $A L K$ inverse prediction models obtained from the Kelly calibration curves for the $3^{\prime}$ and $5^{\prime}$ portions of $A L K$. The model was derived using the $1-50 \%$ dilution series of the external calibration curves. The percentage (\%) of tumor cell content is also indicated for each sample. ALK, anaplastic lymphoma kinase; FISH, fluorescence in situ hybridization; RT-qPCR, quantitative reverse transcription-polymerase chain reaction.

\section{MATERIALS AND METHODS}

\section{Human cell lines and samples}

The human neuroblastoma cell line Kelly (DSMZ ${ }^{\circledR}$ ACC $355^{\mathrm{TM}}$ ) and the lung cancer cell line NCI-H2228 $\left(\mathrm{ATCC}^{\circledR} \mathrm{CRL}-5935^{\mathrm{TM}}\right.$ ) were used as positive controls for the expression of full-length $A L K$ transcript (ALKF1174L mutant) [2] and of translocated $A L K$ (EML4-ALK) [5], respectively. The lung cancer cell line A549 (ATCC ${ }^{\circledR}$ CCL$185^{\mathrm{TM}}$ ) was used as a negative control, since they express barely detectable levels of the normal $A L K$ transcript [5]. Cells were cultured and used fresh or pelleted and processed into FFPE cell blocks for subsequent analyses. Cells were routinely tested for mycoplasma contamination [50] and multiplex short tandem repeat profiling test for authentication using the GenePrint ${ }^{\circledR} 10$ System (Promega Corporation, Madison, WI, USA).

All samples were derived from patients operated at the European Institute of Oncology (IEO), Milan, Italy. FFPE tissue blocks of ALK FISH-positive samples with sufficient biological material were available for 17 patients. Based on the availability of these $17 \mathrm{FISH}-$ positive samples, we randomly selected 34 FISHnegative controls, which together constituted a cohort of 51 NSCLC patients (with a 1:2 ratio of ALK positive $v s$. control samples). We also analyzed 7 cytological samples (cytoblocks), 5 FISH-negative and 2 FISHpositive, with sufficient biological material obtained with the EBUS-TBNA procedure from patients with clinically diagnosed primary lung cancer. The clinico-pathological characteristics of the patients are described in Table 1. RNA was also extracted from FFPE non-pathological lung tissue samples, adjacent to diseased area, prepared from an additional 20 NSCLC patients. Each case was centrally reviewed to confirm the histopathological assessment and to verify the content of tumor or normal parenchyma. Investigations were conducted in accordance with the ethical standards as outlined in the Declaration of Helsinki and in national and international guidelines, and were approved by the IEO institutional review board.

\section{Fluorescence in situ hybridization}

$A L K$ rearrangements were analyzed on $4 \mu \mathrm{m}$ thick FFPE tissue sections, using the break-apart probe FISH Probe Kit (Vysis LSI ALK Dual Color, Abbott Molecular Inc.) according to manufacturer's instructions. Samples were analyzed using an epifluorescence microscope (Leica, Wetzlar, Germany). Signal evaluation was performed in at least 60 nuclei as follows: i) separated green and red signals or single red signals (translocation and deletion of the $A L K 5^{\prime}$ portion) in at least $15 \%$ of tumor cells analyzed; ii) overlapping of green and red signals (yellowish) indicated cells in which $A L K$ was not rearranged.

\section{Immunohistochemistry}

ALK IHC was performed on $4 \mu \mathrm{m}$ thick FFPE tissue sections using the fully automated Ventana IHC ALK (D5F3) CDx Assay (Ventana Medical Systems, 
Inc., Tucson, AZ, USA), with the pre-diluted Ventana anti-ALK (D5F3) rabbit monoclonal primary antibody, the Optiview DAB IHC detection kit and Optiview Amplification kit on the Benchmark XT stainer. We adopted the binary scoring system (positive or negative for ALK status) to evaluate the staining results according to manufacturer's recommendations. ALK positivity was assigned exclusively in the presence of a strong granular cytoplasmic staining in tumor cells (any percentage of positive tumor cells).

\section{RNA extraction and quantitative real-time PCR}

Genetic material was isolated from fresh cell lines using the AllPrep DNA/RNA/miRNA Universal Kit (Qiagen, Hilden, Germany) and from FFPE cell blocks or tissue blocks using the AllPrep DNA/RNA FFPE Kit (Qiagen, Hilden, Germany). RNA was extracted from manually microdissected areas of 2 tissue sections $(10 \mu \mathrm{m}$ thick) on glass slides selected by a pathologist for each relevant FFPE tissue block. For standard mRNA analysis, $500 \mathrm{ng}$ of total RNA (RNA concentration measured using the NanoDrop ${ }^{\circledR}$ ND-1000 Spectrophotometer) were reverse transcribed with random primers using the SuperScript ${ }^{\mathbb{R}}$ VILO $^{\text {TM }}$ cDNA Synthesis Kit (Thermo Fisher Scientific) and $5 \mathrm{ng}$ or $20 \mathrm{ng}$ of cDNA from fresh or FFPE cells, respectively, were then analyzed per reaction by PCR. In case of pre-amplification, 100, 25, and $10 \mathrm{ng}$ (as indicated) of total RNA from FFPE cell blocks and/or FFPE tissue blocks were reverse transcribed, pre-amplified for 10 cycles using the PreAMP Master Mix Kit (Thermo Fisher Scientific) according to manufacturer's instructions, and diluted 1:5 prior to PCR analysis ( $5 \mu 1$ were then used per PCR reaction, corresponding to $2,0.5$ or $0.2 \mathrm{ng}$ of cDNA).

Quantitative PCR was performed with hydrolysis probes (Thermo Fisher Scientific) using the SsoAdvanced Universal Probes Supermix (Bio-Rad Laboratories) in $10 \mu \mathrm{l}$ of final volume in 384-well plates. PCR reaction was run in LightCycler (LC) 480 real-time PCR instruments (Roche) using the following thermal cycling conditions: 1 cycle at $95^{\circ} \mathrm{C}$ for $30 \mathrm{sec}, 45$ cycles at $95^{\circ} \mathrm{C}$ for $5 \mathrm{sec}$, and $60^{\circ} \mathrm{C}$ for $30 \mathrm{sec}$.

TaqMan gene expression assays, with short amplicon sizes, were as follows: Hs01058323_m1 (human ALK, RefSeq NM_004304, exon boundary 9-10, assay location 2775, amplicon length $66 \mathrm{bp}$ ), Hs00608292_m1 (human ALK, RefSeq NM_004304, exon boundary 27-28, assay location 5022, amplicon length 59 bp), Hs03929097_g1 (human GAPDH, RefSeq NM_001256799, exon boundary 8-8, assay location 1250 , amplicon length 58 bp), Hs99999908_m1 (human GUSB, RefSeq NM_000181, exon boundary 11-12, assay location 1925, amplicon length $81 \mathrm{bp}$ ) and Hs00427621 m1 (human TBP, RefSeq NM_001172085, exon boundary 3-4, assay location 666, amplicon length 65 bp) (sequence details in Supplementary Table S9).
We defined $\mathrm{Cq}=40$ as our limit of detection in the absence of pre-amplification and $\mathrm{Cq}=30$ in the presence of the pre-amplification, based on the lowest $\mathrm{Cq}$ value measured for the two ALK assays in the negative control cell line A549 (Supplementary Table S1). Cq values beyond these limits were set to 40 or 30 , accordingly, and normalization was omitted. Each target was assayed in triplicate and average $\mathrm{Cq}$ values were calculated either from triplicate values when the standard deviation was $<0.4$, or from the best duplicate values when the standard deviation was $\geq 0.4$. In each sample, the average $\mathrm{Cq}$ value of the $3^{\prime}$ or $5^{\prime}$ portion of $A L K\left(\mathrm{Cq}_{\mathrm{ALK}}\right)$ was normalized on the average $\mathrm{Cq}\left(\mathrm{Cq}_{\mathrm{REF}}\right)$ value of three human reference genes ( $G A P D H, G U S B$ and $T B P$ ), to account for variation in the expression of single reference genes and in RNA integrity due to tissue fixation, using the following formula:

$$
\Delta \mathrm{Cq}=\mathrm{Cq}_{\mathrm{ALK}}-\text { mean } \mathrm{Cq}_{\mathrm{REF}}
$$

Pre-amplification uniformity for each $A L K$ gene expression assay was measured in Kelly cells by calculating the $\Delta \mathrm{Cq}$ for each of the two ALK assays $\left(\Delta \mathrm{Cq}=\mathrm{Cq}_{3^{\prime} / 5^{\prime} \mathrm{ALK}}-\right.$ mean $\mathrm{Cq}_{\mathrm{REF}}$ ) and by determining the $\Delta \Delta \mathrm{Cq}$ between pre-amplified (PreAmp) and not-preamplified cDNA templates $\left(\Delta \Delta \mathrm{Cq}=\Delta \mathrm{Cq}_{\text {PreAmp }}-\Delta \mathrm{Cq}_{\mathrm{cDNA}}\right)$. Minus-reverse transcriptase ("-RT") controls were also performed for pre-amplified cDNA templates to confirm the specificity of the ALK assays. "-RT" controls were negative both for the $3^{\prime}$ and 5' ALK assays (all samples were flagged as "undetectable"). Based on the distribution of the reference genes, we applied the Tukey's interquartile rule for outliers [51] to identify poor quality RT-qPCR data in the cohort of 51 FFPE NSCLC samples.

\section{Development of the predictive model for the assessment of $A L K$ status in tumor specimens}

We prepared two different calibration curves using an artificial dilution series of total RNA derived from FFPE blocks of either Kelly cells expressing fulllength $A L K$ or NCI-H2228 cells expressing EML4-ALK, mixed with total RNA from $A L K$ negative A549 cells. Each curve was composed of 23 data points, obtained by diluting RNA from positive cells with increasing amounts of RNA from negative cells until a mixture composed of 1\% NCI-H2228/Kelly RNA and 99\% A549 RNA was reached. The upper half of the curve (50-100\% of RNA from positive cells) was obtained using discrete increments of $10 \%$ of RNA from negative cells. To improve the resolution of the ALK assay in the lower half of the calibration curve (0-50\%), RNA from positive cells was diluted using progressively smaller increments of RNA from negative cells as follows: $5 \%$ increments in the $25-50 \%$ range, $2.5 \%$ increments in the $5-25 \%$ range, and $1 \%$ increments in the $1-5 \%$ range. We reverse transcribed 
$500 \mathrm{ng}$ or $100 \mathrm{ng}$ of total RNA for each data point of the calibration curve in the absence or in the presence of preamplification, respectively, prior to PCR analysis.

The level of expression of the $3^{\prime}$ and/or the $5^{\prime}$ portion of the $A L K$ transcript measured by PCR was regressed on the known percentage (log-transformed, base 10) of total $A L K$-positive RNA present in each data point of the calibration curve analyzed. The inverse prediction approach was applied to predict the actual percentage of $3^{\prime}$ and/or 5' $A L K$-positive transcript, as well as $95 \%$ confidence intervals from the values obtained in the RTqPCR analysis [44].

We employed both Kelly and NCI-H2228 calibration curves, separately or pooled, to build the predictive models for the $3^{\prime}$ portion; the Kelly calibration curve alone was used for the $5^{\prime}$ portion of $A L K$. To improve the performance of the assay when ALK is expressed at low/moderate levels in unknown NSCLC samples, we also generated predictive models by including only the data points in the $1-50 \%$ dilution range. Coefficient of determination $\left(R^{2}\right)$ and residual sum of squares (RSS) values were calculated to assess the goodness of the various fits. To evaluate the basal level of expression of both the $5^{\prime}$ and $3^{\prime}$ portions of $A L K$, we applied the different predictive models to the set of 20 lung FFPE non-pathological tissue samples. The threshold value of $A L K$ positivity (abnormal $A L K$ expression) was established based on the median of the 95th percentiles of the predictions obtained from each of the different models. Finally, these inverse predictive models were validated in the cohort of 51 FFPE human samples. Translocation was assigned based on unbalanced interval estimates of $3^{\prime}$ and 5' ALK predictions. Statistical analyses were performed using SAS (SAS 9.3, SAS Institute, Cary, NC, USA).

\section{ACKNOWLEDGMENTS}

We appreciate the efforts of Rosalind Gunby for critically reading the manuscript, and Stefania Pirroni and Giovanna Jodice for technical assistance.

\section{CONFLICTS OF INTEREST}

The authors declare no conflicts of interest.

\section{GRANT SUPPORT}

This work was supported by grants from the Associazione Italiana per la Ricerca sul Cancro (AIRC IG 11904 to SP; IG 10349, IG 14404 and MCO 10.000 to PPDF); the Italian Ministry of University and Scientific Research (MIUR) to PPDF; the Italian Ministry of Health to SP and PPDF; the Monzino Foundation to PPDF; the G. Vollaro Foundation to SP.

\section{REFERENCES}

1. Kutok JL, Aster JC. Molecular biology of anaplastic lymphoma kinase-positive anaplastic large-cell lymphoma. J Clin Oncol. 2002; 20:3691-3702.

2. George RE, Sanda T, Hanna M, Frohling S, Luther W 2nd, Zhang J, Ahn Y, Zhou W, London WB, McGrady P, Xue L, Zozulya S, Gregor VE, et al. Activating mutations in ALK provide a therapeutic target in neuroblastoma. Nature. 2008; 455:975-978.

3. Mosse YP, Laudenslager M, Longo L, Cole KA, Wood A, Attiyeh EF, Laquaglia MJ, Sennett R, Lynch JE, Perri P, Laureys G, Speleman F, Kim C, et al. Identification of ALK as a major familial neuroblastoma predisposition gene. Nature. 2008; 455:930-935.

4. Soda M, Choi YL, Enomoto M, Takada S, Yamashita Y, Ishikawa S, Fujiwara S, Watanabe $\mathrm{H}$, Kurashina $\mathrm{K}$, Hatanaka H, Bando M, Ohno S, Ishikawa $\mathrm{Y}$, et al. Identification of the transforming EML4-ALK fusion gene in non-small-cell lung cancer. Nature. 2007; 448:561-566.

5. Rikova K, Guo A, Zeng Q, Possemato A, Yu J, Haack H, Nardone J, Lee K, Reeves C, Li Y, Hu Y, Tan Z, Stokes M, et al. Global survey of phosphotyrosine signaling identifies oncogenic kinases in lung cancer. Cell. 2007; 131: 1190-1203.

6. Shaw AT, Yeap BY, Mino-Kenudson M, Digumarthy SR, Costa DB, Heist RS, Solomon B, Stubbs H, Admane S, McDermott U, Settleman J, Kobayashi S, Mark EJ, et al. Clinical features and outcome of patients with non-small-cell lung cancer who harbor EML4-ALK. J Clin Oncol. 2009; 27: 4247-4253.

7. Camidge DR, Kono SA, Flacco A, Tan AC, Doebele RC, Zhou Q, Crino L, Franklin WA, Varella-Garcia M. Optimizing the detection of lung cancer patients harboring anaplastic lymphoma kinase (ALK) gene rearrangements potentially suitable for ALK inhibitor treatment. Clin Cancer Res. 2010; 16:5581-5590.

8. Solomon B, Varella-Garcia M, Camidge DR. ALK gene rearrangements: a new therapeutic target in a molecularly defined subset of non-small cell lung cancer. J Thorac Oncol. 2009; 4:1450-1454.

9. Ou SH, Bartlett CH, Mino-Kenudson M, Cui J, Iafrate AJ. Crizotinib for the treatment of ALK-rearranged nonsmall cell lung cancer: a success story to usher in the second decade of molecular targeted therapy in oncology. Oncologist. 2012; 17:1351-1375.

10. Wong DW, Leung EL, Wong SK, Tin VP, Sihoe AD, Cheng LC, Au JS, Chung LP, Wong MP. A novel KIF5BALK variant in nonsmall cell lung cancer. Cancer. 2011; 117:2709-2718.

11. Takeuchi K, Choi YL, Togashi Y, Soda M, Hatano S, Inamura K, Takada S, Ueno T, Yamashita Y, Satoh Y, Okumura S, Nakagawa K, Ishikawa Y, et al. KIF5B- 
ALK, a novel fusion oncokinase identified by an immunohistochemistry-based diagnostic system for ALK-positive lung cancer. Clin Cancer Res. 2009; 15: 3143-3149.

12. Togashi Y, Soda M, Sakata S, Sugawara E, Hatano S, Asaka R, Nakajima T, Mano H, Takeuchi K. KLC1-ALK: a novel fusion in lung cancer identified using a formalin-fixed paraffin-embedded tissue only. PLoS One. 2012; 7:e31323.

13. Majewski IJ, Mittempergher L, Davidson NM, Bosma A, Willems SM, Horlings HM, de Rink I, Greger L, Hooijer GK, Peters D, Nederlof PM, Hofland I, de Jong J, et al. Identification of recurrent FGFR3 fusion genes in lung cancer through kinomecentred RNA sequencing. J Pathol. 2013; 230: 270-276.

14. Hong M, Kim RN, Song JY, Choi SJ, Oh E, Lira ME, Mao M, Takeuchi K, Han J, Kim J, Choi YL. HIP1-ALK, a novel fusion protein identified in lung adenocarcinoma. J Thorac Oncol. 2014; 9:419-422.

15. Salido M, Pijuan L, Martinez-Aviles L, Galvan AB, Canadas I, Rovira A, Zanui M, Martinez A, Longaron R, Sole F, Serrano S, Bellosillo B, Wynes MW, et al. Increased ALK gene copy number and amplification are frequent in non-small cell lung cancer. J Thorac Oncol. 2011; 6:21-27.

16. Perner S, Wagner PL, Demichelis F, Mehra R, Lafargue CJ, Moss BJ, Arbogast S, Soltermann A, Weder W, Giordano TJ, Beer DG, Rickman DS, Chinnaiyan AM, et al. EML4-ALK fusion lung cancer: a rare acquired event. Neoplasia. 2008; 10:298-302.

17. Koivunen JP, Mermel C, Zejnullahu K, Murphy C, Lifshits E, Holmes AJ, Choi HG, Kim J, Chiang D, Thomas R, Lee J, Richards WG, Sugarbaker DJ, et al. EML4-ALK fusion gene and efficacy of an ALK kinase inhibitor in lung cancer. Clin Cancer Res. 2008; 14: 4275-4283.

18. Kwak EL, Bang YJ, Camidge DR, Shaw AT, Solomon B, Maki RG, Ou SH, Dezube BJ, Janne PA, Costa DB, VarellaGarcia M, Kim WH, Lynch TJ, et al. Anaplastic lymphoma kinase inhibition in non-small-cell lung cancer. N Engl J Med. 2010; 363:1693-1703.

19. Shaw AT, Kim DW, Nakagawa K, Seto T, Crino L, Ahn MJ, De Pas T, Besse B, Solomon BJ, Blackhall F, Wu YL, Thomas M, O’Byrne KJ, et al. Crizotinib versus chemotherapy in advanced ALK-positive lung cancer. N Engl J Med. 2013; 368:2385-2394.

20. Solomon BJ, Mok T, Kim DW, Wu YL, Nakagawa K, Mekhail T, Felip E, Cappuzzo F, Paolini J, Usari T, Iyer S, Reisman A, Wilner KD, et al. First-line crizotinib versus chemotherapy in ALK-positive lung cancer. N Engl J Med. 2014; 371:2167-2177.

21. Seto T, Kiura K, Nishio M, Nakagawa K, Maemondo M, Inoue A, Hida T, Yamamoto N, Yoshioka H, Harada M, Ohe Y, Nogami N, Takeuchi K, et al. CH5424802 (RO5424802) for patients with ALK-rearranged advanced non-small-cell lung cancer (AF-001JP study): a single-arm, open-label, phase 1-2 study. Lancet Oncol. 2013; 14:590-598.

22. Shaw AT, Kim DW, Mehra R, Tan DS, Felip E, Chow LQ, Camidge DR, Vansteenkiste J, Sharma S, De Pas T, Riely GJ, Solomon BJ, Wolf J, et al. Ceritinib in ALKrearranged non-small-cell lung cancer. N Engl J Med. 2014; 370:1189-1197.

23. Iwama E, Okamoto I, Harada T, Takayama K, Nakanishi Y. Development of anaplastic lymphoma kinase (ALK) inhibitors and molecular diagnosis in ALK rearrangementpositive lung cancer. Onco Targets Ther. 2014; 7:375-385.

24. Katayama R, Shaw AT, Khan TM, Mino-Kenudson M, Solomon BJ, Halmos B, Jessop NA, Wain JC, Yeo AT, Benes C, Drew L, Saeh JC, Crosby K, et al. Mechanisms of acquired crizotinib resistance in ALK-rearranged lung Cancers. Sci Transl Med. 2012; 4:120ra117.

25. Weickhardt AJ, Aisner DL, Franklin WA, VarellaGarcia M, Doebele RC, Camidge DR. Diagnostic assays for identification of anaplastic lymphoma kinase-positive non-small cell lung cancer. Cancer. 2013; 119:1467-1477.

26. Sholl LM, Weremowicz S, Gray SW, Wong KK, Chirieac LR, Lindeman NI, Hornick JL. Combined use of ALK immunohistochemistry and FISH for optimal detection of ALK-rearranged lung adenocarcinomas. J Thorac Oncol. 2013; 8:322-328.

27. Karachaliou N, Rosell R. Optimal detection of ALK rearranged lung adenocarcinomas. J Thorac Oncol. 2013; 8:255-256.

28. Cabillic F, Gros A, Dugay F, Begueret H, Mesturoux L, Chiforeanu DC, Dufrenot L, Jauffret V, Dachary D, Corre R, Lespagnol A, Soler G, Dagher J, et al. Parallel FISH and immunohistochemical studies of ALK status in 3244 nonsmall-cell lung cancers reveal major discordances. J Thorac Oncol. 2014; 9:295-306.

29. Shan L, Lian F, Guo L, Yang X, Ying J, Lin D. Combination of conventional immunohistochemistry and qRT-PCR to detect ALK rearrangement. Diagn Pathol. 2014; 9:3.

30. Wallander ML, Geiersbach KB, Tripp SR, Layfield LJ. Comparison of reverse transcription-polymerase chain reaction, immunohistochemistry, and fluorescence in situ hybridization methodologies for detection of echinoderm microtubule-associated proteinlike 4-anaplastic lymphoma kinase fusion-positive non-small cell lung carcinoma: implications for optimal clinical testing. Arch Pathol Lab Med. 2012; 136:796-803.

31. Savic S, Diebold J, Zimmermann AK, Jochum W, Baschiera B, Grieshaber S, Tornillo L, Bisig B, Kerr K, Bubendorf L. Screening for ALK in non-small cell lung carcinomas: 5A4 and D5F3 antibodies perform equally well, but combined use with FISH is recommended. Lung Cancer. 2015; 89:104-109.

32. Sasaki T, Rodig SJ, Chirieac LR, Janne PA. The biology and treatment of EML4-ALK non-small cell lung cancer. Eur J Cancer. 2010; 46:1773-1780. 
33. Ying J, Guo L, Qiu T, Shan L, Ling Y, Liu X, $\mathrm{Lu} \mathrm{N}$. Diagnostic value of a novel fully automated immunochemistry assay for detection of ALK rearrangement in primary lung adenocarcinoma. Ann Oncol. 2013; 24:2589-2593.

34. Wynes MW, Sholl LM, Dietel M, Schuuring E, Tsao MS, Yatabe Y, Tubbs RR, Hirsch FR. An international interpretation study using the ALK IHC antibody D5F3 and a sensitive detection kit demonstrates high concordance between ALK IHC and ALK FISH and between evaluators. J Thorac Oncol. 2014; 9:631-638.

35. von Laffert M, Warth A, Penzel R, Schirmacher P, Kerr KM, Elmberger G, Schildhaus HU, Buttner R, Lopez-Rios F, Reu S, Kirchner T, Pauwels P, Specht K, et al. Multicenter immunohistochemical ALK-testing of non-small-cell lung cancer shows high concordance after harmonization of techniques and interpretation criteria. J Thorac Oncol. 2014; 9:1685-1692.

36. Pekar-Zlotin M, Hirsch FR, Soussan-Gutman L, Ilouze M, Dvir A, Boyle T, Wynes M, Miller VA, Lipson D, Palmer GA, Ali SM, Dekel S, Brenner R, et al. Fluorescence in situ hybridization, immunohistochemistry, and next-generation sequencing for detection of EML4ALK rearrangement in lung cancer. Oncologist. 2015; 20: 316-322.

37. Takeuchi K, Choi YL, Soda M, Inamura K, Togashi Y, Hatano S, Enomoto M, Takada S, Yamashita Y, Satoh Y, Okumura S, Nakagawa K, Ishikawa Y, et al. Multiplex reverse transcription-PCR screening for EML4-ALK fusion transcripts. Clin Cancer Res. 2008; 14:6618-6624.

38. Soda M, Isobe $\mathrm{K}$, Inoue $\mathrm{A}$, Maemondo M, Oizumi S, Fujita Y, Gemma A, Yamashita Y, Ueno T, Takeuchi K, Choi YL, Miyazawa H, Tanaka T, et al. A prospective PCRbased screening for the EML4-ALK oncogene in non-small cell lung cancer. Clin Cancer Res. 2012; 18:5682-5689.

39. Wang R, Pan Y, Li C, Hu H, Zhang Y, Li H, Luo X, Zhang J, Fang Z, Li Y, Shen L, Ji H, Garfield D, et al. The use of quantitative real-time reverse transcriptase PCR for 5' and $3^{\prime}$ portions of ALK transcripts to detect ALK rearrangements in lung cancers. Clin Cancer Res. 2012; 18:4725-4732.

40. Gruber K, Horn H, Kalla J, Fritz P, Rosenwald A, Kohlhaufl M, Friedel G, Schwab M, Ott G, Kalla C. Detection of rearrangements and transcriptional upregulation of ALK in FFPE lung cancer specimens using a novel, sensitive, quantitative reverse transcription polymerase chain reaction assay. J Thorac Oncol. 2014; 9:307-315.

41. Kotoula V, Bobos M, Vassilakopoulou M, Tsolaki E, Chrisafi S, Psyrri A, Lazaridis G, Papadopoulou K, Efstratiou I, Michail-Strantzia C, Debelenko LV, Kosmidis P, Fountzilas G. Intact or broken-apart RNA: an alternative concept for ALK fusion screening in non-small cell lung cancer (NSCLC). Appl Immunohistochem Mol Morphol. 2015; 23:60-70.

42. Lira ME, Kim TM, Huang D, Deng S, Koh Y, Jang B, Go H, Lee SH, Chung DH, Kim WH, Schoenmakers EF, Choi YL, Park K, et al. Multiplexed gene expression and fusion transcript analysis to detect ALK fusions in lung cancer. J Mol Diagn. 2013; 15:51-61.

43. Moskalev EA, Frohnauer J, Merkelbach-Bruse S, Schildhaus HU, Dimmler A, Schubert T, Boltze C, Konig H, Fuchs F, Sirbu H, Rieker RJ, Agaimy A, Hartmann A, et al. Sensitive and specific detection of EML4-ALK rearrangements in non-small cell lung cancer (NSCLC) specimens by multiplex amplicon RNA massive parallel sequencing. Lung Cancer. 2014; 84:215-221.

44. Mandrekar JN AC. Inverse Prediction Using $\mathrm{SAS}^{\circledR}$ Software: A Clinical Application. Paper P02-2008 Division of Biostatistics, Mayo Clinic, Rochester, MN. 2008.

45. Camidge DR, Theodoro M, Maxson DA, Skokan M, O'Brien T, Lu X, Doebele RC, Baron AE, Varella-Garcia M. Correlations between the percentage of tumor cells showing an anaplastic lymphoma kinase (ALK) gene rearrangement, ALK signal copy number, and response to crizotinib therapy in ALK fluorescence in situ hybridization-positive nonsmall cell lung cancer. Cancer. 2012; 118:4486-4494.

46. Sun JM, Choi YL, Won JK, Hirsch FR, Ahn JS, Ahn MJ, Park K. A dramatic response to crizotinib in a non-smallcell lung cancer patient with IHC-positive and FISHnegative ALK. J Thorac Oncol. 2012; 7:e36-38.

47. Chihara D, Suzuki R. More on crizotinib. N Engl J Med. 2011; 364:776-777; author reply 778.

48. Wiesner $\mathrm{T}$, Lee $\mathrm{W}$, Obenauf AC, Ran L, Murali R, Zhang QF, Wong EW, Hu W, Scott SN, Shah RH, Landa I, Button J, Lailler N, et al. Alternative transcription initiation leads to expression of a novel ALK isoform in cancer. Nature. 2015; 526:453-457.

49. Pfarr N, Stenzinger A, Penzel R, Warth A, Dienemann H, Schirmacher P, Weichert W, Endris V. High-throughput diagnostic profiling of clinically actionable gene fusions in lung cancer. Genes Chromosomes Cancer. 2015; 55:30-44.

50. Uphoff CC, Drexler HG. Comparative PCR analysis for detection of mycoplasma infections in continuous cell lines. In Vitro Cell Dev Biol Anim. 2002; 38:79-85.

51. Tukey J. Exploratory Data Analysis. Addison-Wesley. 1977:43-44. 